\title{
19. CHARACTERISTICS AND DISTRIBUTION OF NEOGENE TURBIDITES AT SITE 657 (LEG 108, CAP BLANC CONTINENTAL RISE, NORTHWEST AFRICA): VARIATIONS IN TURBIDITE SOURCE AND CONTINENTAL CLIMATE ${ }^{1}$
}

\author{
Jean Claude Faugères, ${ }^{2}$ Philippe Legigan, ${ }^{2}$ Noëlle Maillet, ${ }^{2}$ Michael Sarnthein,${ }^{3}$ and Ruediger Stein ${ }^{4}$
}

\begin{abstract}
Numerous and variable silty-sandy siliciclastic turbidites were observed in Neogene pelagic sediments (late Miocene to Holocene) at Site 657: (1) thick-bedded, coarse-grained and thin-bedded, fine-grained turbidites; and (2) turbidites composed of eolian dune sand and shallow-water bioclasts or of fluvial-sand or mixed sandy component assemblages.

The stratigraphic distribution of these turbidites indicates five periods during which climatic conditions and material sources change. Turbidite occurrence prior to $6.2 \mathrm{Ma}$ (late Miocene) is sparse; the deposits contain coarse and fine-grained turbidites with quartz grains of eolian or mixed origin suggesting the existence of arid conditions at about 8.5 and $6.5 \mathrm{Ma}$. A coarse-grained turbidite of fluvial origin, recording a humid climate, occurs at about $6.2 \mathrm{Ma}$. During the early Pliocene, turbidites are frequent (15/Ma); they contain only fine-grained sequences comprising material of mixed origin, which indicates a more humid climate perhaps. The late Pliocene starts with rare coarse-grained turbidites of wind-transported sand while the uppermost Pliocene deposits show a higher frequency of fine-grained sequences (10/0.7 Ma) composed mainly of fluvial material. During the early Pleistocene, similar high turbidite frequency was observed $(20 / 1.3 \mathrm{Ma}$ ) but with a total lack of eolian supply. During the last $0.7 \mathrm{Ma}$, the frequency decreases and the sequences are characterized by highly variable sediment components that could be related to strong variations of climatic conditions.

The sedimentary characteristics of turbidites are mainly controlled by sediment source and climate. The frequency must be influenced by sea-level variations, by cyclic processes of climatic origin, and possibly by variations in the continental slope morphology. Clay mineral assemblages suggest a south Saharan source of terrigenous material during the late Miocene and the Pliocene and a northwest Saharan source during the Pleistocene.
\end{abstract}

\section{INTRODUCTION}

Site 657 on Ocean Drilling Program (ODP) Leg 108 (Ruddiman, Sarnthein, et al., 1988) is located on the northwest African continental rise at a water depth of $4220 \mathrm{~m}, 380 \mathrm{~km}$ west of Cap Blanc (Fig. 1). Holes 657A and 657B were cored on the smooth plain of a distal turbidite fan, yielding a well-layered, thick, and relatively undisturbed seismic sequence. The sediment sequence recovered from these holes is $178 \mathrm{~m}$ thick and ranges from late Miocene to Holocene in age.

Two main sedimentary units (Fig. 2) can be distinguished (Ruddiman, Sarnthein, et al., 1988): Unit I (Hole 657A, $0-146.2 \mathrm{mbsf}$ ) ranges from early Pliocene to Holocene with predominantly nannofossil ooze; and Unit II (Hole 657A, 146.2-178.2 mbsf), late Miocene in age, is composed of brownish silty clay with low carbonate contents.

These two units are separated by a late Miocene-early Pliocene hiatus $(6.2-4.6 \mathrm{Ma})$. They both contain numerous sandy-silty siliciclastic layers of variable thickness $(2 \mathrm{~cm}$ to $3.8 \mathrm{~m}$ ) and two conspicuous slumps interbedded in pelagic and hemipelagic sediments. Because recovery was very good, we assumed that the total thickness of coarse-grained layers and slumps represents $30 \%-35 \%$ of the overall sedimentation. The lower slump (96.5-124.5 mbsf) consists of folded nannofossil

\footnotetext{
${ }^{1}$ Ruddiman, W., Sarnthein, M., et al., 1989. Proc. ODP, Sci. Results, 108: College Station, TX (Ocean Drilling Program).

2 Laboratoire de Géologie-Océanographie, Université de Bordeaux I, Avenue des Facultés, Talence 33405 Cedex, France.

${ }^{3}$ Geologisch-Paläontologisches Institut, Universität Kiel, Olshausenstrasse 40 , D-2300 Kiel, Federal Republic of Germany.

${ }^{4}$ Institut für Geowissenschaften und Lithosphärenforschung, Universität Giessen, Senckenbergstrasse 3, 6300 Giessen, Federal Republic of Germany.
}

ooze cycles and is $28 \mathrm{~m}$ thick (Günther, 1988). The upper slump (11.6-26.2 mbsf) is composed of two debris flows interbedded with turbiditic beds. The slumps represent $23 \%-$ $24 \%$ of the total sediment thickness. Eighty coarse-grained layers were identified in Hole 657B, which account for $10 \%$ $12 \%$ of the sediment pile.

In this paper, we concentrate on the characteristics and implications of individual coarse-grained layers and associated sequences. The study of coarse-grained layers provides many clues to a number of problems regarding deep-sea environments and sediment transport processes as well as paleogeographic and climatic conditions on the adjacent continent and continental shelf. Many authors, such as Berger and von Rad (1972), Hayes et al. (1972), Sarnthein and Diester-Haass (1977), Sarnthein (1978), Moyes et al. (1979), Sarnthein et al. (1982), and Jacobi and Hayes (1982), show evidence to support the idea that downslope transport processes, in coarse-grained layers, predominate on the Cap Blanc rise, despite the presence of sediments deposited by contour currents. Many layers have, in fact, been interpreted as turbidite sequences, some of which are called "eolian-sand turbidites" (Sarnthein and Diester-Haass, 1977) and which could indicate low sea-level stands with a strand line close to the shelf edge and/or an ancient desert environment with an offshore wind regime linked to an arid climatic belt.

By examining the sandy-silty layers, we obtained information about two major topics:

1. The first topic is concerned with the basic classification of the different kinds of beds and sequences that resulted from different depositional processes and sources of sediment origin, linked closely to sea-level fluctuations and changes in continental climate conditions. Most coarse-grained layers are related to gravity processes and, specifically, to turbidity 


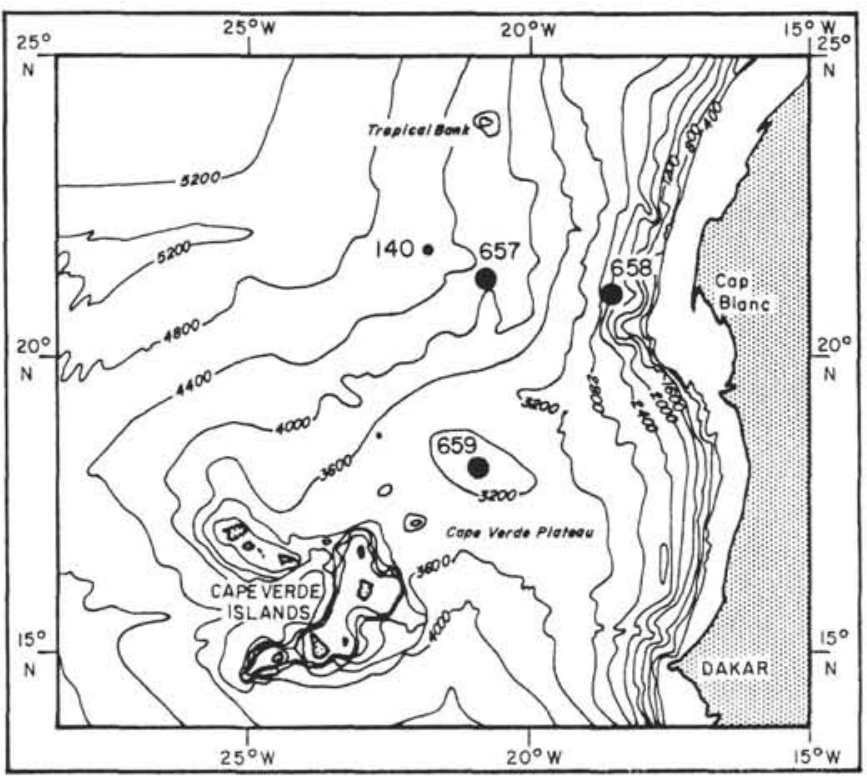

Figure 1. Location of Ocean Drilling Program Sites 657, 658, and 659 and Deep Sea Drilling Project Site 140 (contours in meters).

currents. A few sandy-silty layers may be contourites deposited during phases of pronounced bottom-current activity (Jacobi and Hayes, 1982).

2. The second topic deals with the stratigraphic distribution of the different kinds of coarse-grained sediment layers throughout the Neogene, allowing the reconstruction of the sedimentary response to major changes in paleogeography, sea-level fluctuations, climatic variation, source supply along the continental margin and on land, and possibly such oceanographic events as the influence of bottom currents and changes in upwelling intensity. The stratigraphic distribution of these layers may also aid age determinations of the "eoliansand turbidites" observed in neighboring Deep Sea Drilling Project (DSDP) Site 140 (Sarnthein, 1978).

\section{METHODS}

The biostratigraphic and paleomagnetic results during Leg 108 (Ruddiman, Sarnthein, et al., 1988) provided a detailed chronology of the sediment recovered from Holes $657 \mathrm{~A}$ and $657 \mathrm{~B}$. This data also provided reliable stratigraphic correlations between both cores from these holes. Core recovery at Holes $657 \mathrm{~A}$ and $657 \mathrm{~B}$ amounted to about $85 \%$, which offers an almost complete overview of the coarsegrained layer distribution throughout the section.

Visual observations of the layers were made on JOIDES Resolution. Sediment sample slices $6 \mathrm{~cm}$ long, $3 \mathrm{~cm}$ wide, and $1 \mathrm{~cm}$ thick were taken on board for shore-based analysis. Samples were placed in plastic bags covered with polyester to avoid disintegration. In the Bordeaux laboratory, these samples were split into two halves: one was impregnated in order to study microstructure and microfacies characteristics in thin section, while the other half was divided into as many parts (parallel to the laminae; $1-\mathrm{cm}^{3}$ subsamples) as possible.

The various samples obtained in this way ( 23 thin sections and 50 free particulate samples) were used to study structures and microstructures related to hydrodynamic origin, grain-size characteristics (obtained with a French Afnor sieves series for coarse-grained sediments and with a Sedigraph for fine-grained samples), sand component distribution (quantitative or semiquantitative analysis with the binocular microscope), and shape and surface characteristics of quartz (scanning electron microscope [SEM]).

For each turbidite sequence analyzed, samples for component studies have been taken from the different facies divisions: one sample, at least, for each facies type, but more than one for the coarse-grained $\mathrm{A}-\mathrm{B}$ or $\mathrm{C}$ divisions of each turbidite, according to the Bouma sequence (1962). These analyses focused mainly on the components of the sand and clay fraction and were performed on loose sediment after wet sieving with $63-$ and $150-\mu \mathrm{m}$ sieves.

Furthermore, modal analyses were made from the thin sections. More than 25 sand components (including siliciclastic and authigenic components, pelagic and benthic foraminifers, shallow-water bioclasts, and others) were distinguished. The component diversity in a single sample was generally low. Thus, the percentage of the constituent particles were generally estimated only semiquantitatively.

Quantitative estimates were made for a few characteristic samples based on a count of 250 or 300 grains. In addition, mineralogical analyses were performed on bulk sediment samples, using X-ray diffractometry (clay minerals, feldspars, feldspar/quartz ratio). Further analyses were made on the surface of impregnated sediment slides with an energy dispersive spectrometer coupled with the SEM to determine, in particular, the distribution of iron in the sand fraction.

\section{RESULTS}

\section{Coarse-Grained Layers: Turbidites or Contourites?}

The coarse-grained layers plotted on Figure 2 show the following characteristics: (1) all basal contacts are sharp and/or erosional (in contrast, the coarse-grained facies, near the base of the layers, gradually passes into the overlying fine-grained pelagic deposits, except for the coarsest layers, in which the contact between these two facies is rather sharp); (2) grain-size gradation is positive (fine grains on top of coarse grains) except for turned-over deposits in folded slumps; (3) all facies changes follow the rules of the Bouma turbiditic sequence (1962), but mainly of truncated sequences (with upper or lower or even middle sections missing); and (4) bioturbation structures are concentrated in the upper proportion of the layer only, following turbidite characteristics.

Based on the criteria of contour current-controlled sedimentation as defined by Fritz and Pilkey (1975), Stow and Piper (1984), Faugères et al. (1984b), and Gonthier et al. (1984), we conclude that siliciclastic contourites are largely absent in the Neogene deposits at Site 657 and relate all coarse-grained layers to processes of turbiditic sedimentation resulting in large variability in bedding, thickness, grain size, and components. Each coarse layer is considered as the product of a separate turbidite event and is henceforth named "turbidite sequence."

Based on sediment thickness and grain size, two main groups of sequences can be distinguished: coarse-grained, thick-bedded turbidites (T1) and fine-grained, thin-bedded turbidites (T2). Moreover, three types of sediment supplyeolian, fluvial, and mixed-could be deduced from the sediment composition, reflecting different regimes of climate and paleogeography along the West African margin.

\section{Structural and Textural Characteristics of the Turbidite Sequences}

\section{Coarse-Grained, Thick-Bedded Turbidites}

Seven coarse-grained, thick-bedded turbidites (T1) with a thickness range from 0.4 to $3.85 \mathrm{~m}$ were found throughout the Neogene section (Fig. 2). Their basal facies are composed mainly of siliciclastic and calcareous sands and silty sands. We were able to distinguish two types of incomplete turbidite sequences sensu Bouma (1962) from their vertical structural and textural evolution (Figs. 3 and 4 and Plate 1).

Type la (T1a) starts with an erosional basal surface, which is the base of a massive sand A division (0.5-3.85 m thick), directly overlain by massive or weakly bioturbated pelagic ooze equivalent to Bouma's E division. The contact between the two facies divisions is sharp. Internal structures are absent in the sandy A division, except for a slight positive grading (Plate 2C). The sand 
657A

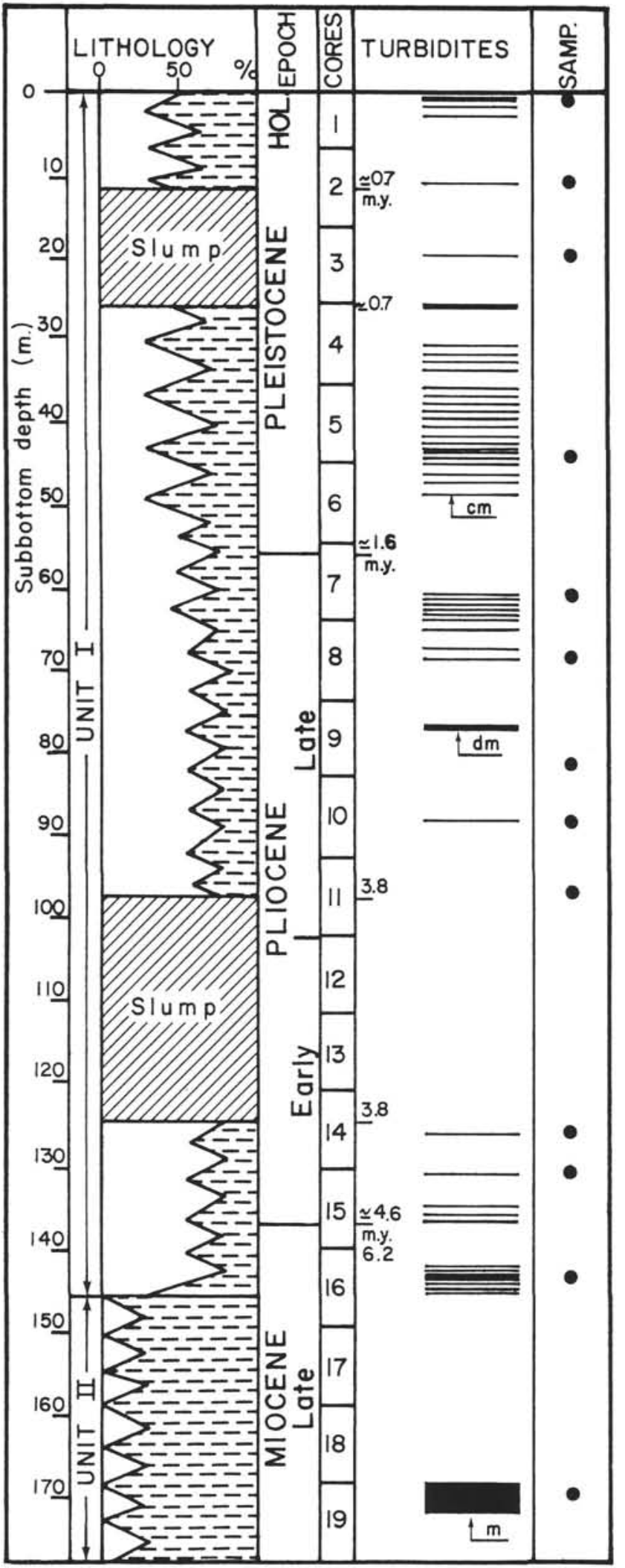

$657 B$

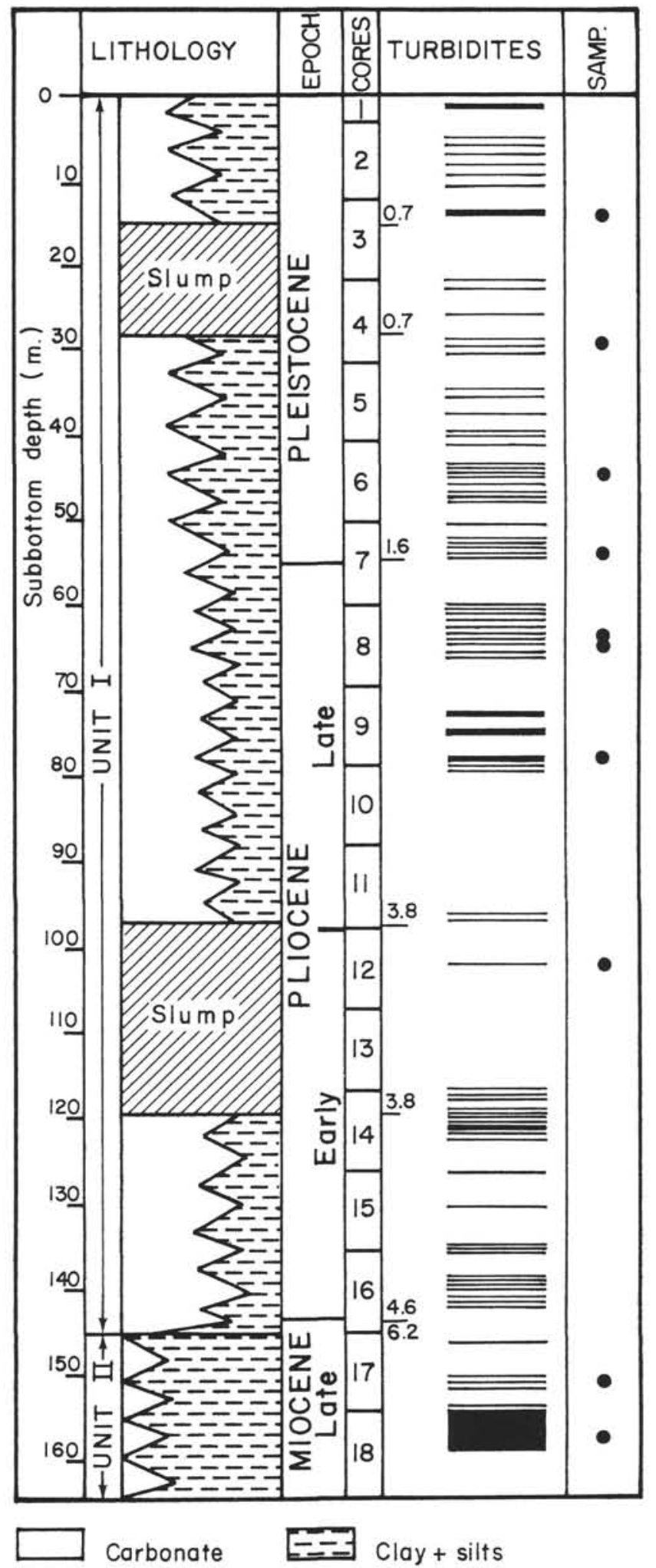

Figure 2. Lithology and stratigraphy at Site 657, based on results in Ruddiman, Sarnthein, et al., 1988. Vertical distribution of metric (m), decimetric $(\mathrm{dm})$, and centimetric $(\mathrm{cm})$ turbiditic sequences. Lithologic and stratigraphic position of the analyzed samples. 


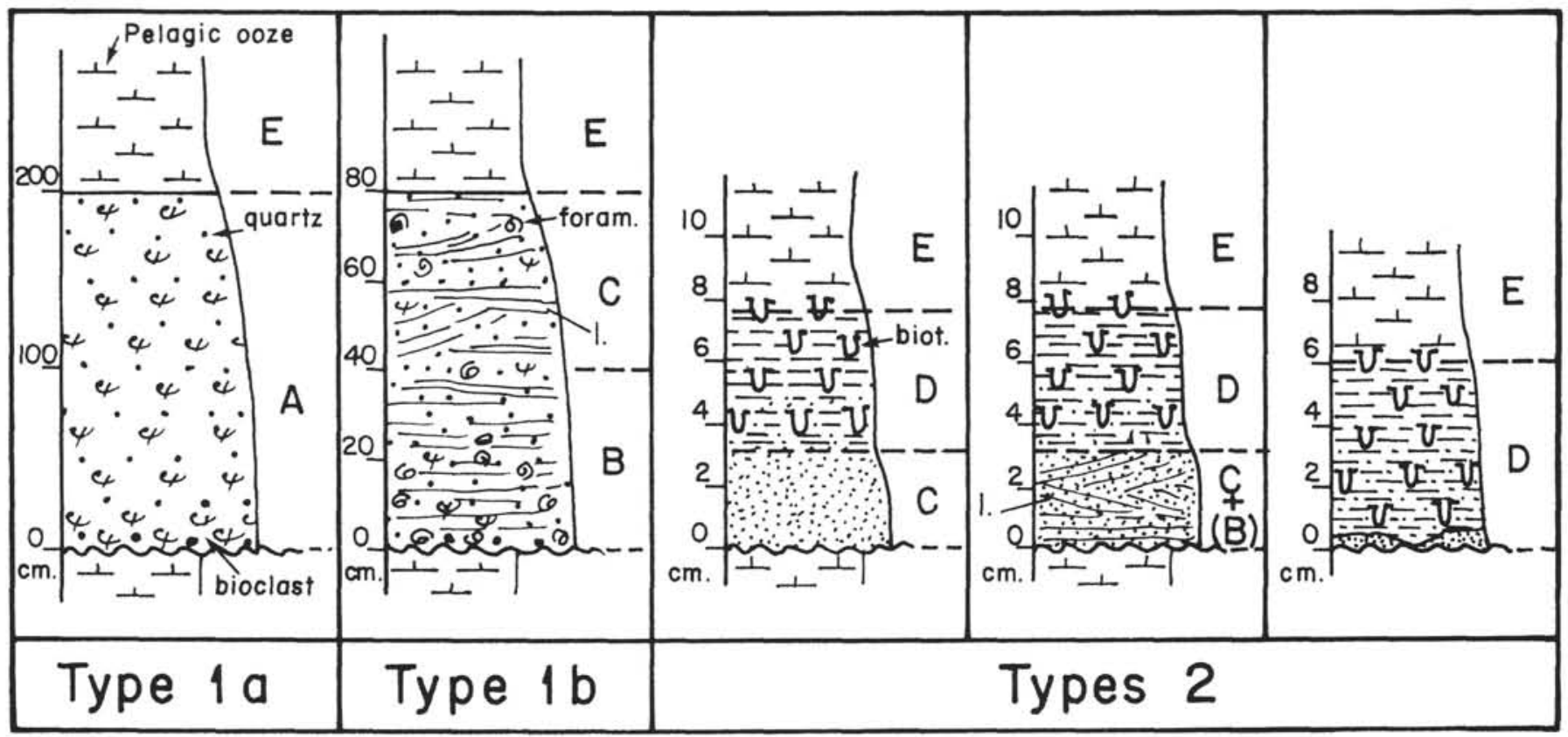

Figure 3. Different types of turbidite sequences. Type la (T1a): coarse-grained, thick-bedded massive A-E sequence (eolian-sand turbidite). Type $1 \mathrm{~b}$ (T1b): coarse-grained, thick-bedded laminated B-C-E sequence (fluvial-sand turbidite). Type 2 (T2): characteristics of fine-grained, thin-bedded laminated or massive C-D-E or D-E sequences (various sediment origins). foram. = foraminifers, 1. = laminations, and biot. = bioturbation.

fraction, at the base of the A division (Fig. $4 \mathrm{~A}$ and Table 1) generally represents $50 \%-95 \%$ of the sediment, with only minor amounts of silt and $<5 \%$ clay. The median sand diameter ranges from 250 to $140 \mu \mathrm{m}$. Sorting is very good (Table 1).

The maximum diameter of the quartz grains is $2.2 \mathrm{~mm}$ while that of the calcareous bioclastic particles reaches 3.4 $\mathrm{mm}$. The carbonate content is high, varying from $35 \%$ to $80 \%$ of the sediment, and it apparently increases with grain size. When turbidites are deposited under the carbonate compensation depth (CCD), the absence of dissolution features within calcareous tests could be due to rapid deposition and burial. This interpretation is supported by the fact that the carbonate content still amounts to $35 \%$ in an upper Miocene sand (Core 108-657B-18H) that was deposited below the CCD in brownish clay (Ruddiman, Sarnthein, et al., 1988).

With regard to the Bouma model, the turbidites in T1a are top cutout (A-E) sequences. They may indicate a large-scale supply of continental sediments that have been deposited in a proximal position on the continental rise in specific environments such as major channels (facies A and B in Mutti and Ricci-Lucchi, 1974; Normark, 1978; Walker, 1978). Their transport requires a dense, high-velocity flow. The general absence of silt and clay and the very good sorting of the sand suggest that these turbidites result from grain-flow processes (Middleton and Hampton, 1973). The absence of intermediate B-C-D divisions might be due to the original characteristics of the sediment source, such as, for example, well-sorted, eolian dune sand (Sarnthein and Diester-Haass, 1977).

The second type of coarse-grained, thick-bedded turbidites (T1b) is characterized by a base cutout and a top cutout sequence with B-C-E or C-E divisions (Fig. 3). As in Tla, this sequence commences with a basal sandy division overlain by white grayish pelagic ooze. In contrast to the basal sands of turbidites Tla, the sands of T1b contain abundant currentbedding structures, occurring in the form of graded or nongraded laminated units a few millimeters thick. Therefore, the sands have been attributed to a B or $\mathrm{C}$ division. The transition to the overlying ooze (E division) is more or less gradual. The muddy $\mathrm{D}$ division is missing because of a lack of clay ( $5 \%$ or less). The basal sediment is formed by well-sorted fine sands with a median diameter ranging from 80 to $60 \mu \mathrm{m}$ and a major silty fraction that accounts for about $30 \%$ of the bulk sediment (Fig. 4B and Table 1).

Detailed analyses of the T1b basal B or C division by means of thin indurated sample sections enabled us to recognize two kinds of microlaminated structures (Plates 1 and 2). The first fabric type shows alternating horizontal laminations $1 \mathrm{~mm}$ to 1 $\mathrm{cm}$ thick (Plate 2A). These laminations are formed either by sandy-silty quartz and accessory carbonate particles and/or by coarse-grained bioclastic and foraminifer ooze with a minor siliciclastic fraction. Although dispersed irregularly, the laminae show an upward gradational increase in quartz contents. In this example, a 2-cm-thick carbonate-rich layer, close to the basal erosional contact, contains a few wispy quartz-rich laminations $<1 \mathrm{~mm}$ thick. Further upcore, quartz-rich laminations become thicker and more frequent. At the top of the section, quartz is largely predominant with respect to the carbonate matrix. This distribution pattern is characteristic of the B division as defined by Middleton and Hampton (1973).

The second type of microlaminations observed in the basal member exhibits the superposition of microsequences $0.7-1.4$ $\mathrm{cm}$ thick. These microsequences are composed of three layers with gradational transitions (Plate 2B): (1) Above a sharp basal surface, the first layer is composed of massive ooze $(3-5 \mathrm{~mm})$, with abundant foraminifers and bioclasts and some sparse silty or sandy quartz. (2) The overlying layer $(2-4 \mathrm{~mm})$ is characterized by quartz-rich carbonate ooze with horizontal and oblique laminations. (3) At the top, a third layer (3-7 mm) is composed mostly of silty-sandy quartz with some foraminifers and bioclasts scattered or concentrated in wispy laminations.

Four similar microsequences were observed at the base of a sandy turbidite (Section 108-657A-16H-3, 80-86 cm; Plate 2B). All of them display positive grading with foraminifer-bioclastrich, coarse-grained layers at the base and quartz-rich, fine- 

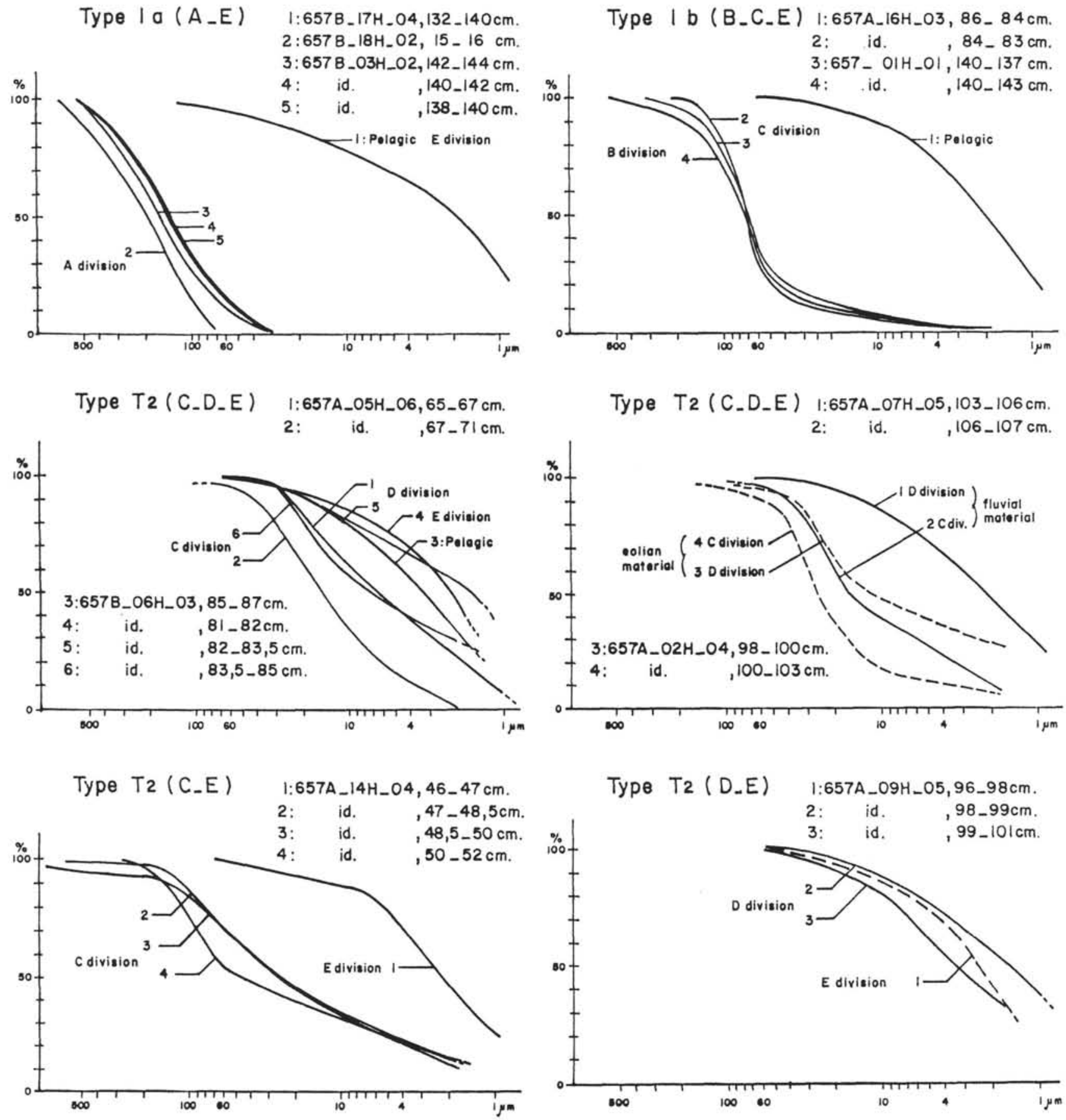

Figure 4. Typical grain-size cumulative frequency curves plotted on semilogarithmic paper for the different types of turbidite sequences.

grained layers at the top. The upward increase of quartz particles could be due both to a finer grain size and a lower grain density of quartz vs. calcareous particles. The microsequences are probably the relict of ripple bedforms built by traction currents. They are characteristic of the $\mathrm{C}$ division in a $\mathrm{C}-\mathrm{E}$ sequence (Middleton and Hampton, 1973; Cremer, 1983).

In both cases (B-C-E and C-E sequences), internal structures and sequential deposition result from classical turbidity current processes. By contrast with T1a turbidites, a deposition by grain flow processes is unlikely. Grain-size characteristics suggest that $\mathrm{T} 1 \mathrm{~b}$ turbidites were also formed by high-density and high-velocity currents and may occur closely to Tla deposit environments. The low clay concentrations and good sorting of the sand could be the result of both a particular sediment source (the erosion of well-sorted sandstone or eolian deposits) or an overall sorting process during transport. For example, turbidity currents that carry river-born clayey-silty sands may first deposit the coarse particles on the rise while the finer particles can be carried out to the distal abyssal plain. These processes are known to generate top cutout and base cutout sequences in ancient or modern sediments (Mutti and Ricci-Lucchi, 1984; Stow, 1984). 
Table 1. Structural and textural characteristics of the turbiditic sequences at Holes 657A and 657B.

\begin{tabular}{|c|c|c|c|c|c|c|c|c|c|c|c|}
\hline $\begin{array}{r}\text { sequence } \\
\text { number }\end{array}$ & \begin{tabular}{|c|} 
thickness \\
$\mathrm{cm}$
\end{tabular} & structures & $\begin{array}{rr}\mathrm{sec} \\
\text { samples }(\mathrm{cm}) \\
\end{array}$ & $\begin{array}{l}\text { quences } \\
\text { divisions }\end{array}$ & $\begin{array}{c}\% \\
\mathrm{CaCO} 3 \\
\end{array}$ & $\begin{array}{c}\% \\
>150 \mu \mathrm{m} \\
\end{array}$ & $\begin{array}{c}\% \\
<63 \mu \mathrm{m} \\
\end{array}$ & $\begin{array}{c}\% \\
\text { clay }\end{array}$ & \begin{tabular}{|c|} 
median- \\
diam. $(\mu \mathrm{m})$ \\
\end{tabular} & sorting & $\begin{array}{l}\text { sequence } \\
\text { types }\end{array}$ \\
\hline $657 \mathrm{~A}-1 \mathrm{H}-1$ & 40 & lam. & $137-140$ & $\bar{C}$ & 20 & 8 & 30 & $<5$ & 75 & 1.4 & \begin{tabular}{|ll} 
Tlb B.C.E. \\
B.
\end{tabular} \\
\hline \multirow[t]{2}{*}{$137-140 \mathrm{~cm}$} & & & $140-143$ & B & 23 & 13 & 27 & $<5$ & 78 & 1.5 & \\
\hline & & & $143-144$ & pelagite & 70 & - & 68 & 18 & 10 & 6.3 & \\
\hline \multirow{2}{*}{$\begin{array}{c}657 \mathrm{~A}-2 \mathrm{H}-4 \\
98-104 \\
\end{array}$} & 3 & lam. & $98-100$ & D & 12 & 2 & 96 & 30 & 12 & 3.4 & $\mathrm{CDE}$ \\
\hline & & & $100-103$ & C & 28 & 1 & 92 & 8 & 15 & 2.9 & \\
\hline \multirow{3}{*}{$\begin{array}{c}657 \mathrm{~B}-3 \mathrm{H}-2 \\
138-144\end{array}$} & 82 & \begin{tabular}{|l|} 
massive \\
\end{tabular} & $138-140$ & $\bar{A}$ & 56 & 46 & 15 & - & 140 & 1.6 & T1a \\
\hline & & & $140-142$ & A & 61 & 49 & 15 & - & 150 & 1.6 & \\
\hline & & & $142-144$ & A & 68 & 55 & 12 & - & 160 & 1.7 & \\
\hline \multirow{3}{*}{$\begin{array}{c}657 \mathrm{~A}-3 \mathrm{H}-3 \\
100-106\end{array}$} & 4 & microsq. & $100-102$ & $\mathrm{C}$ & 48 & - & 82 & 30 & 18 & 2.9 & T2 $\mathrm{CDE}$ \\
\hline & & & $102-104$ & C & 50 & - & 90 & 35 & 15 & 2.8 & \\
\hline & & & $105-106$ & C & 25 & - & 100 & 15 & 8 & 1.5 & \\
\hline \multirow{3}{*}{$\begin{array}{c}657 \mathrm{~B}-4 \mathrm{H}-5 \\
46-54\end{array}$} & 2 & \begin{tabular}{|l|} 
massive \\
\end{tabular} & $46-50$ & $\bar{D}$ & 35 & - & 99 & 35 & 2 & 2.5 & $\overline{\mathrm{CDE}}$ \\
\hline & & & $50-52$ & D & 25 & - & 98.5 & 38 & 2,5 & 2.6 & \\
\hline & & & $52-54$ & C & 30 & - & 99 & 10 & 6,5 & 1.9 & \\
\hline \multirow{2}{*}{$\begin{array}{c}657 \mathrm{~A}-5 \mathrm{H}-6 \\
65-71 \\
\end{array}$} & 2 & massive & $65-67$ & D & 27 & - & 99.5 & 25 & 06 & 2.4 & $\mathrm{CDE}$ \\
\hline & & & $67-70$ & C & 25 & 1 & 95 & $<5$ & 14 & 1.7 & \\
\hline \multirow{4}{*}{$\begin{array}{c}657 \mathrm{~B}-6 \mathrm{H}-3 \\
81-87\end{array}$} & 1.5 & \begin{tabular}{|l|} 
massive \\
\end{tabular} & $81-82$ & E & 36 & - & 99 & 45 & $\overline{\mathrm{O} 2}$ & 2.6 & T2 $\mathrm{CDE}$ \\
\hline & & & $82-83.5$ & D & 23 & - & 99 & 55 & $\mathrm{O} 2$ & 2.4 & \\
\hline & & & $83.5-85$ & C & 24 & - & 99 & 30 & 07 & 2.8 & \\
\hline & & & $85-87$ & pelagite & 55 & - & 99 & 30 & 3.5 & 2.2 & \\
\hline \multirow{4}{*}{$\begin{array}{c}657 \mathrm{~A}-6 \mathrm{H}-3 \\
77-83\end{array}$} & & & $77-78.5$ & pelagite & 46 & - & 98 & 35 & $\mathrm{O} 2$ & $?$ & \\
\hline & Pelagite & no & $78.5-81$ & pelagite & 30 & - & 99 & 41 & $?$ & ? & Pelagite \\
\hline & & & $81-82$ & pelagite & 38 & - & 97.5 & 40 & $?$ & $?$ & \\
\hline & & & $82-83$ & pelagite & 71 & - & 94 & 23 & ? & ? & \\
\hline $657 \mathrm{~B}-7 \mathrm{H}-3$ & 1.5 & lam. & $24-26$ & $\mathrm{D}$ & 30 & - & 99.5 & 29 & $?$ & $?$ & $\mathrm{~T} 2 \mathrm{CDE}$ \\
\hline $24-30$ & & & $26-27$ & C & 35 & - & 98.5 & 05 & 12 & 1.7 & \\
\hline & & & $27-29$ & pelagite & 38 & - & 98.5 & 35 & $?$ & $?$ & \\
\hline $\begin{array}{c}657 \mathrm{~B}-7 \mathrm{H}-1 \\
123-129\end{array}$ & 1.5 & lam. & $124-125$ & $\mathrm{C}$ & 30 & - & 98 & 7 & 18 & 2.2 & T2 $\quad \mathrm{CDE}$ \\
\hline $657 \mathrm{~A}-7 \mathrm{H}-5$ & 1.5 & massive & $103-106$ & $\bar{D}$ & 26 & - & 100 & 45 & 02.5 & 2.4 & $\mathrm{~T} 2 \mathrm{CDE}$ \\
\hline $103-109$ & & & $106-107$ & C & 33 & - & 95 & 10 & 16 & 2.4 & \\
\hline & & & $107-108$ & pelagite & 55 & - & 96 & 34 & $?$ & $?$ & \\
\hline $657 \mathrm{~B}-8 \mathrm{H}-3$ & 6 & microsq. & $74-76$ & $\mathrm{C}$ & 23 & $=$ & 98 & 15 & 8 & 2.4 & $\overline{C D E}$ \\
\hline $74-80$ & & & $76-77$ & C & 25 & - & 99 & 14 & 7 & 2.4 & \\
\hline & & & $77-79$ & C & 26 & . & 80 & 10 & 27 & 2.0 & \\
\hline $657 \mathrm{~B}-8 \mathrm{H}-3$ & 4 & lam. & $85-86$ & D & 41 & - & 92.5 & 50 & 2 & 2.4 & $\overline{\mathrm{CDE}}$ \\
\hline $85-91$ & & & $86-87$ & C & 38 & - & 94 & 20 & 4.5 & 2.4 & \\
\hline & & & $87-88.5$ & C & 36 & - & 91 & 13 & 6 & 2.2 & \\
\hline & & & $88.5-90$ & C & 41 & - & 33 & 2 & 85 & 2.0 & \\
\hline & & & $90-91$ & pelagite & 80 & - & 95 & 24 & 3 & 2.4 & \\
\hline $\begin{array}{c}657 \mathrm{~A}-8 \mathrm{H}-4 \\
7-13\end{array}$ & 2 & massive & $11-12$ & C & 27 & - & 90 & 12 & 9 & 2.3 & T2 CDE \\
\hline $657 \mathrm{~B}-9 \mathrm{H}-6$ & 50 & \begin{tabular}{|l|} 
massive \\
\end{tabular} & $94-96$ & $\overline{\mathrm{A}}$ & 82 & 71 & 18 & $<5$ & 250 & 2.1 & T1a \\
\hline $94-100$ & & & 96-98 & A & 80 & 68 & 21 & $<5$ & 220 & 2.1 & \\
\hline & & & $98-99$ & A & 80 & 65 & 23 & $<5$ & 205 & 2.1 & \\
\hline & & & $99-100$ & pelagite & 60 & - & 100 & 30 & 03.5 & 2.6 & \\
\hline $657 \mathrm{~A}-9 \mathrm{H}-5$ & 0.3 & lam. & $96-98$ & $\mathrm{E}$ & 76 & $=$ & 98.4 & 45 & 02.5 & 2.1 & $\overline{D E}$ \\
\hline $96-102$ & & & 98-99 & D & 65 & - & 99.3 & 57 & 01.6 & 2.2 & \\
\hline & & & 99-101 & D & 55 & - & 99.5 & 60 & 1.5 & 2.2 & \\
\hline $657 \mathrm{~A}-10 \mathrm{H}-4$ & 2 & massive & $136-137$ & $\bar{E}$ & 54 & $=$ & 99 & 50 & 01.5 & 2.2 & $\mathrm{CDE}$ \\
\hline $136-142$ & & & $137-138$ & D & 43 & . & 99.5 & 55 & 01.8 & 2.2 & \\
\hline & & & $138-140$ & D & 40 & . & 99.5 & 42 & 03.5 & 2.2 & \\
\hline & & & $140-142$ & C & 40 & . & 100 & 40 & 4 & 2.1 & \\
\hline $657 \mathrm{~B}-12 \mathrm{H}-3$ & 1 & \begin{tabular}{|l|} 
massive \\
\end{tabular} & $69-71$ & $C+D$ & 15 & $=$ & 99.5 & 60 & 2 & 2.4 & $\mathrm{CDE}$ \\
\hline & & & 71.75 & pelagite & 74 & - & 87 & 35 & 4 & 2.8 & \\
\hline $657 \mathrm{~A}-14 \mathrm{H}-4$ & 5 & \begin{tabular}{|l|} 
massive \\
\end{tabular} & $46-47$ & $\mathrm{E}$ & 60 & - & 98.5 & 44 & 2.5 & 2.2 & $\mathrm{CE}$ \\
\hline $46-52$ & & & $47-48.5$ & C & 41 & 10 & 72.5 & 16 & 26 & 3.3 & \\
\hline & & & $48.5-50$ & C & 38 & 08.5 & 72 & 15 & 27 & 3.3 & \\
\hline & & & $50-51.5$ & C & 36 & 6.5 & 56.5 & 15 & 40 & 3.4 & \\
\hline $657 \mathrm{~A}-15 \mathrm{H}-1$ & 2 & massive & $104-105$ & E & 65 & - & 97 & 40 & 2.5 & 2.0 & $\overline{\mathrm{CDE}}$ \\
\hline $104-110$ & & & $106-107$ & C & 46 & 5.5 & 56.7 & 10 & 10 & 2.8 & \\
\hline & & & $108-110$ & pelagite & 78 & - & 96.5 & 15 & $?$ & $?$ & \\
\hline $657 \mathrm{~A}-16 \mathrm{H}-3$ & 50 & \begin{tabular}{|l|} 
microsq. \\
\end{tabular} & $80-81$ & $\mathrm{C}$ & 33 & 2 & 49 & 5 & 61 & 1.7 & $\mathrm{Tlb}$ \\
\hline & & & $81-83$ & C & 41 & 3.8 & 49 & 5 & 62 & 1.7 & \\
\hline & & & $83-84$ & C & 25 & 1.5 & 41.5 & $<5$ & 70 & 1.4 & \\
\hline & & & $84-86$ & pelagite & 65 & - & 98.5 & 35 & 2.5 & 2.4 & \\
\hline $657 \mathrm{~B}-17 \mathrm{H}-4$ & 4 & \begin{tabular}{|l|} 
massive \\
\end{tabular} & $134-135.5$ & D & $\mathrm{O} 3$ & - & 91.3 & 60 & 2 & 5.0 & T2 $\mathrm{CDE}$ \\
\hline $134-140$ & & & $135.5-137$ & C & $\mathrm{O} 3$ & 9 & 70 & 34 & 24 & 2.8 & \\
\hline & & & $138-139$ & C & 2 & 15 & 22.3 & 15 & 90 & 2.6 & \\
\hline & & & $139-140$ & pelagite & 2 & . & 90 & 54 & 1.8 & 3.1 & \\
\hline $\begin{array}{c}657 \mathrm{~B}-18 \mathrm{H}-2 \\
15-16\end{array}$ & 160 & massive & $15-16$ & A & 35 & 65 & 01 & 0 & 190 & 1.7 & T1a \\
\hline
\end{tabular}

Note: Column labeled "Thickness $(\mathrm{cm})^{\prime \prime}=$ thickness of the sandy-silty basal terms of the sequences. Column labeled "Structures" = massive, laminated (lam.) or with microsequences (microsq.). Column labeled "\% $<63 \mu \mathrm{m}$ " includes silts and clay percentages (sand fraction $\%=100 \%-\%<63 \mu \mathrm{m}$ ). See Table 2. Sequence divisions according to Bouma, 1962. 


\section{Fine-Grained, Thin-Bedded Turbidites}

Fine-grained, thin-bedded turbidites (T2, $<10 \mathrm{~cm}$ thick) are frequent throughout the Neogene sediment pile cored at Site 657 (Fig. 2). Moreover, 70 turbidite sequences were counted at Hole $657 \mathrm{~B}$, consisting of a basal terrigenous sediment member that ranges from a few centimeters to $10 \mathrm{~cm}$ in thickness and is composed mainly of silt and clay. Internal facies variations (Figs. 3 and 4 , Plates 1 and 3, and Table 1) outline the C-D-E divisions that correspond to the top of the Bouma sequence or to fine-grained turbidite sequences (Stow and Shanmugan, 1980), with a specific array of sedimentary structures (Faugères et al., 1984a; Cremer and Stow, 1986).

The $\mathrm{C}$ division (1-6 cm thick) is usually composed of sandy-clayey silts with a median diameter of 4-40 $\mu \mathrm{m}$. The clay content represents $5 \%-40 \%$ of the bulk sediment (Table 1 ), while the sand fraction ranges between $1 \%$ and $40 \%$ and exceptionally up to $>50 \%$ (Table 2 ). These sediments are well to moderately sorted and, in some cases, even badly sorted. Typically, a very thin, millimeter-thick sand bed with a maximum median grain diameter of $90 \mu \mathrm{m}$ lies just above the erosional basal surface of the sequence. The facies is mainly composed of siliciclastic material and less calcareous material $\left(\mathrm{CaCO}_{3}\right.$ content ranging from $3 \%$ to $50 \%$; Table 2). In many cases, the $\mathrm{C}$ division is massive with a slight positive grading. Scattered coarse sandy particles outline the scoured-like depressions of the basal contact. In some sequences, special internal structures are present: (1) wispy laminations are highlighted by slight variations in the concentration of calcareous particles (foraminifers and bioclasts; Plate $3 \mathrm{~A}$ ); (2) wispy or sharp calcareous laminations may be more or less discontinuous in a silty quartz layer (Plate 3B); (3) horizontal or cross-bedded sharp laminations may result from alternations of dominantly terrigenous or calcareous material (Plate 3C); (4) laminated microsequences of the same thickness and with the same internal facies divisions as those described for the C-E coarsegrained sequence of the T1b turbidites (Plate 3D).

The $\mathrm{D}$ division consists of silty clay with thicknesses from a few centimeters to $10 \mathrm{~cm}$ and with a clay percentage ranging from $60 \%$ to $40 \%$ and exceptionally $<40 \%$. The median grain diameter varies from 12 to $<2 \mu \mathrm{m}$, and sorting may be moderate to poor. Calcareous material $(3 \%-55 \%)$ is equal or slightly less abundant than in the $\mathrm{C}$ division due to a decrease of the sandy fraction (Table 2) and, therefore, in the absolute sandy biogenic particle content. Bioturbation structures are common and filled with white to gray pelagic ooze. Wispy and irregular laminations occur at the base of this member. Facies transitions are gradual to the underlying $\mathrm{C}$ and overlying $\mathrm{E}$ divisions.

The $\mathrm{E}$ division shows a progressive increase in carbonate content and is capped by pelagic foraminifer nannofossil ooze. This transitional zone between the siliciclastic and pelagic facies members is very thin: a few centimeters above the D division, carbonates already account for $50 \%-60 \%$ of the bulk sediment, values which are very close to those recorded from true pelagic ooze. Further above, pelagic sediments form a homogeneous layer or a "climatic sequence" (Faugères et al., this vol.) of variable thickness.

This means that the siliciclastic facies members (C-D divisions and base of $\mathrm{E}$ division) constitute a thin upwardgraded turbiditic sequence that is usually $<10 \mathrm{~cm}$ thick, Most of these sequences are composed of three members, but some of them may be incomplete with $\mathrm{D}$ and $\mathrm{E}$ divisions only (108-657A-9H-5, 96-102 cm).

In contrast to the T1 turbidites, fine-grained, thin-bedded turbidites are probably the result of turbidity currents of lower density and velocity. Conventionally, they are related to distal deep-sea environments on the abyssal plain far from channel inlets. However, the example of Site 657 shows that they may be present on the rise as well in interchannel zones or in channel levees.

Only a few reverse-graded sequences were observed on board (108-657A-15H-1, 104-110 cm, or 108-657A-15H-4, $72-78 \mathrm{~cm}$ ), which were considered as contourites. However, they are incorporated into slump deposits and display the same characteristics as T2 sequences, with the exception of the reversed-graded bedding. Hence, we now consider them to be also normal turbidites that have been reversed by sediment folding during the slump transport.

\section{Modal Composition of Turbidites}

There are a number of problems in attempting to compare and interpret the particle composition of sands from different turbidites. The sand fraction is strongly variable in abundance and grain size. In some cases, it is so small and fine grained that the samples cannot furnish sufficient data on the diversity and abundance of components, the quartz roundness, and the origin of bioclasts. On the other hand, samples from coarsegrained sand turbidites show different components and percentages in the fine, medium, and coarse sand fraction. To highlight the differences between different turbidites, we compare data from the same grain-size fractions, in general, the fine sand fraction $(63-160 \mu \mathrm{m})$.

Moreover, our comparisons are based on (1) quartz-grain exoscopy (Le Ribault, 1977), (2) the nature and proportion of different feldspar types in the bulk sediment, (3) the feldspar/ quartz ratio (percentage of bulk sediment), (4) the clay mineral assemblages, and, for some samples, (5) the abundance and distribution of hematite in the sand fraction (Tables 2 and 3 ).

\section{Sand Components}

Siliciclastic components are usually dominant in the various sand fractions near the base of the turbidites, with percentages of $95 \%-50 \%$ and occasionally $<50 \%$. The main component is quartz. Other minerals such as feldspar, mica, and heavy minerals are rare or less common.

Quartz often comprises $50 \%$ of the fine sand fraction. It may be uncolored or transparent or have a reddish stain; some stained spots and coatings of hematite were also observed. The grains may be angular, subrounded, or well-rounded; in some medium sands, frosted grains predominate over various other kinds of grains. Exoscopic analysis allowed a more detailed differentiation of the grain types (Plate 4), as follows.

1. Reworked eolian-sand grains bear numerous crescentshaped features of eolian origin that have been more or less smoothed in the aquatic environment. The presence of clean surfaces with grooved features due to dissolution processes as well as the presence of solution networks are related to the subsequent evolution of the grain surface in the marine environment.

2. Fresh eolian-sand grains differ from sand grain category 1 (above) by having better preserved, sharper crescent-shaped features that have not been smoothed. However, all grains present evidence of subsequent evolution under marine conditions. In some grains, surface depressions containing silica overgrowths of a possibly intertidal origin have been observed in association with slight secondary dissolution marks, which indicate a residence period in an infratidal environment.

3. Fluvial quartz grains show silica overgrowths only on plane faces or in small depressions of the grain. In some cases, diatoms of deltaic origin have been cemented by the silica overgrowths to the grain surface. 
Table 2. Component assemblages in turbiditic sequences at Holes 657A and 657B.

\begin{tabular}{|c|c|c|c|c|c|c|c|c|c|c|c|c|c|c|c|c|c|c|c|c|c|c|c|c|c|c|}
\hline 1 & & 2 & 3 & 4 & 5 & \multicolumn{5}{|c|}{6} & \multicolumn{2}{|l|}{7} & \multirow{2}{*}{\begin{tabular}{|c|}
8 \\
$F / Q$
\end{tabular}} & \multirow{2}{*}{\begin{tabular}{|c|}
9 \\
Micas \\
\end{tabular}} & \multirow{2}{*}{\begin{tabular}{|c|}
10 \\
$\begin{array}{c}\text { Heavy } \\
\text { mineral }\end{array}$ \\
\end{tabular}} & \multirow{2}{*}{$\frac{11}{\text { Pyritc }}$} & \multirow{2}{*}{\begin{tabular}{|c|}
12 \\
$\begin{array}{c}\text { Biog. } \\
\%\end{array}$
\end{tabular}} & \multirow{2}{*}{$\begin{array}{c}13 \\
\text { pl. F. } \\
\%\end{array}$} & \multirow{2}{*}{\begin{tabular}{|c|}
14 \\
s.w.b. \\
$\%$
\end{tabular}} & \multirow{2}{*}{\begin{tabular}{|c}
15 \\
bth. F. \\
$\%$
\end{tabular}} & \multirow{2}{*}{$\begin{array}{l}16 \\
\text { sil. }\end{array}$} & \multirow{2}{*}{\begin{tabular}{|c|}
17 \\
ostr. \\
\end{tabular}} & \multirow{2}{*}{\begin{tabular}{|c|}
18 \\
ech. \\
\end{tabular}} & \multirow{2}{*}{\begin{tabular}{c|}
19 \\
$\begin{array}{c}\text { component } \\
\text { assemblage }\end{array}$ \\
\end{tabular}} & \multicolumn{2}{|l|}{20} \\
\hline $\begin{array}{l}\text { Num } \\
\text { sam }\end{array}$ & $\begin{array}{l}\text { iber } \\
\text { ples }\end{array}$ & $\begin{array}{l}\text { sequenc } \\
\text { types }\end{array}$ & $\begin{array}{c}\mathrm{CaCO} 3 \\
\%\end{array}$ & $\begin{array}{c}\text { Sand } \\
\%\end{array}$ & $\begin{array}{c}\text { silicicl. } \\
\%\end{array}$ & $\%$ & & $\begin{array}{l}\text { Ruartz } \\
\text { fluv. }\end{array}$ & mar. & & $\begin{array}{l}\text { Felds } \\
\mathrm{K}\end{array}$ & $\begin{array}{l}\text { par } \\
\mathrm{CaNa}\end{array}$ & & & & & & & & & & & & & epochs & \\
\hline $657 \mathrm{~A}-1 \mathrm{H}-1$ & \begin{tabular}{|l|}
$137-140$ \\
$140-143$
\end{tabular} & Tlb C & $\begin{array}{l}20 \\
23\end{array}$ & $\begin{array}{l}70 \\
73\end{array}$ & $\begin{array}{l}75 \\
50\end{array}$ & $\begin{array}{l}65 \\
45\end{array}$ & - & $\mathrm{P}$ & A & $\mathrm{P}$ & 6 & $\begin{array}{l}8 \\
5\end{array}$ & \begin{tabular}{|c|}
$?$ \\
0.3
\end{tabular} & $\begin{array}{l}\mathrm{P} \\
\mathrm{P}\end{array}$ & R & . & $\begin{array}{l}25 \\
50\end{array}$ & $\begin{array}{l}15 \\
40\end{array}$ & $\begin{array}{l}5 \\
5\end{array}$ & \begin{tabular}{|l|}
5 \\
5
\end{tabular} & $\begin{array}{l}\mathrm{P} \\
\mathrm{P}\end{array}$ & - & - & M.Fl. & & \\
\hline $657 \mathrm{~B}-2 \mathrm{H}-4$ & $\begin{array}{r}98-100 \\
100-103\end{array}$ & $T 2$ & $\begin{array}{l}12 \\
28\end{array}$ & $\begin{array}{l}4 \\
8\end{array}$ & $\begin{array}{l}10 \\
70\end{array}$ & $\begin{array}{l}8 \\
40\end{array}$ & - & $\mathrm{R}$ & A & $\mathrm{P}$ & - & $\begin{array}{l}14 \\
36\end{array}$ & \begin{tabular}{|l|}
0.5 \\
1.2 \\
\end{tabular} & - & - & - & $\begin{array}{l}90 \\
30\end{array}$ & $\begin{array}{l}80 \\
20\end{array}$ & 5 & 5 & $\begin{array}{l}\mathrm{A} \\
\mathrm{A}\end{array}$ & $\therefore$ & - & M.Eol. & & \\
\hline $657 \mathrm{~B}-3 \mathrm{H}-2$ & \begin{tabular}{l|}
$138-140$ \\
$140-142$ \\
$142-144$
\end{tabular} & T1a & $\begin{array}{l}56 \\
61 \\
68\end{array}$ & $\begin{array}{l}85 \\
85 \\
88\end{array}$ & $\begin{array}{l}30 \\
40 \\
30\end{array}$ & $\begin{array}{l}20 \\
25 \\
20\end{array}$ & TA & - & A & $\mathrm{R}$ & $\begin{array}{l}8 \\
? \\
?\end{array}$ & $\begin{array}{l}2 \\
? \\
?\end{array}$ & $\begin{array}{c}0.7 \\
? \\
?\end{array}$ & - & $\begin{array}{l}\mathrm{P} \\
\mathrm{P} \\
\mathrm{P}\end{array}$ & $\begin{array}{l}\mathrm{P} \\
\mathrm{P}\end{array}$ & $\begin{array}{l}70 \\
60 \\
70\end{array}$ & $\begin{array}{c}20 \\
5 \\
10\end{array}$ & $\begin{array}{l}40 \\
50 \\
50\end{array}$ & $\begin{array}{l}5 \\
5 \\
5\end{array}$ & \begin{tabular}{l|}
$\mathrm{R}$ \\
$\mathrm{R}$ \\
$\mathrm{P}$
\end{tabular} & R & $\begin{array}{l}\mathrm{R} \\
-\end{array}$ & Eol. & $0.7 \mathrm{my}$ & 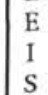 \\
\hline $657 \mathrm{~A}-3 \mathrm{H}-3$ & $\begin{array}{l}100-102 \\
102-104 \\
104-106\end{array}$ & $\mathrm{~T} 2$ & $\begin{array}{l}48 \\
50 \\
25\end{array}$ & $\begin{array}{l}18 \\
3 \\
1\end{array}$ & $\begin{array}{l}60 \\
10 \\
20\end{array}$ & $\begin{array}{c}40 \\
8 \\
15\end{array}$ & A & - & $\bar{A}$ & $\mathrm{P}$ & $\begin{array}{l}8 \\
5 \\
?\end{array}$ & $\begin{array}{c}16 \\
14 \\
?\end{array}$ & \begin{tabular}{|c|}
1.2 \\
1 \\
$?$ \\
\end{tabular} & $\begin{array}{l}\mathrm{R} \\
- \\
\end{array}$ & $\begin{array}{l}\mathrm{R} \\
\mathrm{R} \\
\end{array}$ & $\begin{array}{l}\mathrm{R} \\
\mathrm{R} \\
\end{array}$ & $\begin{array}{l}40 \\
90 \\
80\end{array}$ & $\begin{array}{l}15 \\
65 \\
60\end{array}$ & $\begin{array}{c}20 \\
10 \\
5\end{array}$ & $\begin{array}{c}5 \\
15 \\
15\end{array}$ & . & $\begin{array}{l}\mathrm{R} \\
-\end{array}$ & . & Eol. & & T \\
\hline $657 \mathrm{~B}-4 \mathrm{H}-5$ & $\begin{array}{c}46-50 \\
52-50 \\
54-52\end{array}$ & $\mathrm{~T} 2$ & $\begin{array}{l}33 \\
25 \\
28\end{array}$ & $\begin{array}{c}1 \\
1,5 \\
1\end{array}$ & $\begin{array}{l}10 \\
15 \\
20\end{array}$ & $\begin{array}{c}5 \\
10 \\
15\end{array}$ & & & & & $\begin{array}{c}4 \\
10 \\
4 \\
\end{array}$ & $\begin{array}{l}12 \\
16 \\
18 \\
\end{array}$ & \begin{tabular}{|l|}
0.6 \\
0.4 \\
0.7
\end{tabular} & $\begin{array}{l}\mathrm{A} \\
\mathrm{P} \\
\mathrm{P}\end{array}$ & - & $\begin{array}{l}\mathrm{P} \\
\mathrm{P} \\
-\end{array}$ & $\begin{array}{l}90 \\
85 \\
80\end{array}$ & $\begin{array}{l}80 \\
55 \\
55\end{array}$ & $\begin{array}{c}5 \\
15 \\
10\end{array}$ & $\begin{array}{c}5 \\
10 \\
10\end{array}$ & $\overline{\mathrm{A}}$ & 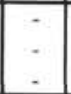 & R & M.Fl. & & $\Gamma$ \\
\hline $657 \mathrm{~A}-5 \mathrm{H}-6$ & $\begin{array}{l}65-67 \\
67-70 \\
\end{array}$ & 12 & $\begin{array}{l}27 \\
25 \\
\end{array}$ & $\begin{array}{l}1 \\
5 \\
\end{array}$ & $\begin{array}{l}60 \\
80 \\
\end{array}$ & $\begin{array}{l}45 \\
60 \\
\end{array}$ & & & & & $\begin{array}{l}4 \\
?\end{array}$ & $\begin{array}{c}14 \\
?\end{array}$ & \begin{tabular}{|c|}
0.6 \\
$?$ \\
\end{tabular} & $\begin{array}{l}\mathrm{P} \\
\mathrm{P}\end{array}$ & - & $\begin{array}{l}\mathrm{A} \\
\mathrm{A}\end{array}$ & $\begin{array}{l}40 \\
20\end{array}$ & $\begin{array}{l}40 \\
20\end{array}$ & $\therefore$ & : & $\therefore$ & . & . & Fl. & & \\
\hline $657 \mathrm{~B}-6 \mathrm{H}-3$ & $\begin{array}{c}81-82 \\
83,5-82 \\
84-85\end{array}$ & T2 & $\begin{array}{l}36 \\
23 \\
24\end{array}$ & $\begin{array}{l}1 \\
1 \\
1\end{array}$ & $\begin{array}{c}0 \\
5 \\
50\end{array}$ & $\begin{array}{l}0 \\
5 \\
40\end{array}$ & & & & & $\begin{array}{c}4 \\
3 \\
10\end{array}$ & $\begin{array}{l}11 \\
10 \\
16\end{array}$ & \begin{tabular}{|c|}
1 \\
0.6 \\
0.8
\end{tabular} & $\begin{array}{l}- \\
\mathrm{P} \\
\mathrm{R}\end{array}$ & - & $\begin{array}{l}\bar{A} \\
\mathrm{~A}\end{array}$ & $\begin{array}{c}100 \\
95 \\
50\end{array}$ & $\begin{array}{l}98 \\
90 \\
50\end{array}$ & - & $\begin{array}{l}2 \\
5 \\
-\end{array}$ & . & - & . & Fl. & & \\
\hline $657 \mathrm{~B}-7 \mathrm{H}-3$ & $\begin{array}{l}24-26 \\
26-27\end{array}$ & $\overline{T 2}$ & $\begin{array}{l}30 \\
35\end{array}$ & $\begin{array}{c}1 \\
1,5\end{array}$ & $\begin{array}{c}5 \\
50\end{array}$ & $\begin{array}{c}5 \\
45\end{array}$ & & & & & $\begin{array}{l}4 \\
?\end{array}$ & $\begin{array}{l}8 \\
?\end{array}$ & \begin{tabular}{|c|}
0.6 \\
$?$
\end{tabular} & - & - & $\begin{array}{l}\mathrm{P} \\
\mathrm{A}\end{array}$ & $\begin{array}{l}95 \\
50 \\
\end{array}$ & $\begin{array}{l}75 \\
30 \\
\end{array}$ & $\begin{array}{c}5 \\
10 \\
\end{array}$ & $\begin{array}{c}10 \\
5 \\
\end{array}$ & - & - & p & M. & & \\
\hline $657 \mathrm{~A}-7 \mathrm{H}-1$ & $124-125$ & $\mathrm{~T} 2$ & 30 & 2 & 60 & 40 & & & & & $?$ & $?$ & $?$ & $\bar{R}$ & - & $\mathrm{P}$ & 40 & 30 & 5 & 5 & $=$ & - & - & M. & & \\
\hline $657 \mathrm{~A}-7 \mathrm{H}-5$ & \begin{tabular}{l|}
$103-106$ \\
$106-107$
\end{tabular} & T2 & $\begin{array}{l}26 \\
33\end{array}$ & $\begin{array}{l}0 \\
5\end{array}$ & $\begin{array}{c}0 \\
40\end{array}$ & $\begin{array}{c}0 \\
35\end{array}$ & & $\mathrm{TA}$ & $\mathrm{R}$ & $K$ & $\begin{array}{l}? \\
2\end{array}$ & $\begin{array}{l}? \\
8\end{array}$ & \begin{tabular}{|c|}
$?$ \\
0.7 \\
\end{tabular} & p & - & p & $\begin{array}{l}0 \\
60\end{array}$ & $\begin{array}{c}0 \\
55\end{array}$ & 0 & $\begin{array}{l}0 \\
5\end{array}$ & $\dot{R}$ & - & . & Fl. & & \\
\hline \begin{tabular}{|l|}
$657 \mathrm{~B}-8 \mathrm{H}-3$ \\
\end{tabular} & $\begin{array}{l}74-76 \\
76-77 \\
77-79\end{array}$ & $\mathrm{~T} 2$ & $\begin{array}{l}23 \\
25 \\
26\end{array}$ & $\begin{array}{c}2 \\
1 \\
20\end{array}$ & $\begin{array}{l}60 \\
50 \\
60\end{array}$ & $\begin{array}{l}40 \\
40 \\
40\end{array}$ & & & & & $\begin{array}{c}12 \\
10 \\
?\end{array}$ & $\begin{array}{l}30 \\
16 \\
?\end{array}$ & \begin{tabular}{|c|}
1.4 \\
0.6 \\
$?$
\end{tabular} & - & $\begin{array}{l}- \\
\mathrm{R} \\
\mathrm{P}\end{array}$ & $\begin{array}{l}\mathrm{A} \\
\mathrm{A} \\
\mathrm{A}\end{array}$ & $\begin{array}{l}40 \\
50 \\
40\end{array}$ & $\begin{array}{l}10 \\
15 \\
20\end{array}$ & $\begin{array}{l}25 \\
30 \\
10\end{array}$ & $\begin{array}{c}5 \\
5 \\
10\end{array}$ & $\therefore$ & . & p & Eol. & $\begin{array}{l}1 \\
a \\
t\end{array}$ & \\
\hline $657 \mathrm{~B}-8 \mathrm{H}-3$ & $\begin{array}{l}85-86 \\
86-87\end{array}$ & & $\begin{array}{l}41 \\
38 \\
\end{array}$ & $\begin{array}{c}7.5 \\
6\end{array}$ & $\begin{array}{l}0 \\
5\end{array}$ & $\begin{array}{l}0 \\
3 \\
\end{array}$ & & & & & $\begin{array}{c}3 \\
15 \\
\end{array}$ & $\begin{array}{l}10 \\
20 \\
\end{array}$ & $\begin{array}{l}0.8 \\
1.6 \\
\end{array}$ & - & - & - & $\begin{array}{c}100 \\
95 \\
\end{array}$ & $\begin{array}{l}70 \\
80 \\
\end{array}$ & 5 & $\begin{array}{l}20 \\
10 \\
\end{array}$ & $\therefore$ & - & $\begin{array}{l} \\
P \\
\end{array}$ & M.Pel. & e & F \\
\hline $657 \mathrm{~A}-8 \mathrm{H}-4$ & $11-12$ & $\mathrm{~T} 2$ & 27 & 10 & 50 & 40 & & & & & $?$ & $?$ & $?$ & $\bar{A}$ & - & - & 50 & 45 & - & 5 & - & $=$ & - & M. & & L \\
\hline $657 \mathrm{~B}-9 \mathrm{H}-6$ & $\begin{array}{l}94-96 \\
96-98\end{array}$ & T1a & $\begin{array}{l}82 \\
80\end{array}$ & $\begin{array}{l}82 \\
78\end{array}$ & $\begin{array}{l}20 \\
20\end{array}$ & $\begin{array}{l}15 \\
15\end{array}$ & $\mathrm{P}$ & - & $\mathrm{P}$ & TA & $\begin{array}{l}? \\
2\end{array}$ & $\begin{array}{l}? \\
8\end{array}$ & \begin{tabular}{|c|}
$?$ \\
1.6
\end{tabular} & - & $\begin{array}{l}\mathrm{P} \\
\mathrm{P}\end{array}$ & $\begin{array}{l}\mathrm{P} \\
\mathrm{P}\end{array}$ & $\begin{array}{l}80 \\
80\end{array}$ & $\begin{array}{l}5 \\
5\end{array}$ & $\begin{array}{l}70 \\
70\end{array}$ & $\begin{array}{l}5 \\
5\end{array}$ & $\therefore$ & : & . & Eol. & & I \\
\hline $657 \mathrm{~A}-9 \mathrm{H}-5$ & $99-101$ & $\mathrm{~T} 2$ & 55 & 0,5 & 0 & 0 & & & & & $?$ & $?$ & $?$ & - & - & - & 100 & 75 & 10 & 15 & - & . & $\bar{R}$ & M.Pel. & & C \\
\hline $657 \mathrm{~A}-10 \mathrm{H}-4$ & \begin{tabular}{l|}
$138-140$ \\
$140-142$
\end{tabular} & $\mathrm{T2}$ & $\begin{array}{l}40 \\
40\end{array}$ & $\begin{array}{c}0.5 \\
0\end{array}$ & $\begin{array}{l}0 \\
0\end{array}$ & $\begin{array}{l}0 \\
0\end{array}$ & & & & & $\begin{array}{l}2 \\
1\end{array}$ & $\begin{array}{l}6 \\
2\end{array}$ & \begin{tabular}{|c|}
1 \\
0.6
\end{tabular} & . & - & . & $\begin{array}{l}? \\
0\end{array}$ & $\begin{array}{l}? \\
0\end{array}$ & $?$ & $\begin{array}{l}? \\
0\end{array}$ & $\therefore$ & . & $?$ & M. & & E \\
\hline $657 \mathrm{~B}-12 \mathrm{H}-3$ & $69-71$ & T2 C-I & 15 & 0,5 & 45 & 40 & & & & & $?$ & ? & $?$ & $\bar{R}$ & $\mathrm{P}$ & - & 55 & 40 & 10 & 5 & - & . & - & M. & $\mathrm{e}$ & E \\
\hline $657 \mathrm{~A}-14 \mathrm{H}-4$ & $\begin{array}{c}46-47 \\
47-48,5 \\
48,5-50 \\
50-52\end{array}$ & T2 & $\begin{array}{l}61 \\
41 \\
38 \\
36 \\
\end{array}$ & $\begin{array}{l}1,5 \\
28 \\
31 \\
44 \\
\end{array}$ & $\begin{array}{l}80 \\
65 \\
45 \\
50\end{array}$ & $\begin{array}{l}75 \\
60 \\
25 \\
40\end{array}$ & & & & & $\begin{array}{l}2 \\
2 \\
? \\
4\end{array}$ & $\begin{array}{c}2 \\
9 \\
? \\
15 \\
\end{array}$ & \begin{tabular}{|c|}
0.5 \\
0.5 \\
$?$ \\
1 \\
\end{tabular} & : & $\begin{array}{l}- \\
\text { P } \\
\text { R }\end{array}$ & $\begin{array}{l}\mathrm{R} \\
\mathrm{P} \\
\mathrm{A} \\
\mathrm{P}\end{array}$ & $\begin{array}{l}20 \\
35 \\
55 \\
50 \\
\end{array}$ & $\begin{array}{l}10 \\
25 \\
30 \\
25 \\
\end{array}$ & $\begin{array}{c}5 \\
5 \\
10 \\
10 \\
\end{array}$ & $\begin{array}{c}5 \\
5 \\
10 \\
10 \\
\end{array}$ & $\begin{array}{l}- \\
- \\
-\end{array}$ & . & $\begin{array}{l}- \\
R \\
P \\
P\end{array}$ & M. & $\begin{array}{l}\mathrm{a} \\
\mathrm{r} \\
1 \\
\mathrm{y}\end{array}$ & \\
\hline $657 \mathrm{~A}-15 \mathrm{H}-1$ & $106-107$ & $\mathrm{~T} 2$ & 46 & 43 & $?$ & $?$ & & & & & 2 & 3 & \begin{tabular}{|l|}
$0 ; 5$ \\
\end{tabular} & $?$ & $?$ & $?$ & $?$ & $?$ & $?$ & $?$ & - & - & $?$ & $?$ & $4.6 \mathrm{M.a}$ & \\
\hline $657 \mathrm{~A}-16 \mathrm{H}-3$ & $\begin{array}{l}80-81 \\
81-83 \\
83-84\end{array}$ & Tib & $\begin{array}{l}33 \\
41 \\
25\end{array}$ & $\begin{array}{l}54 \\
56 \\
62\end{array}$ & $\begin{array}{l}50 \\
50 \\
80\end{array}$ & $\begin{array}{l}35 \\
40 \\
70\end{array}$ & - & $\mathrm{P}$ & $\mathrm{TA}$ & $\mathrm{P}$ & $?$ & $?$ & $?$ & $\begin{array}{l}\text { P } \\
\text { R }\end{array}$ & - & $\begin{array}{l}\mathrm{A} \\
\mathrm{P} \\
\mathrm{P}\end{array}$ & $\begin{array}{l}50 \\
50 \\
20\end{array}$ & $\begin{array}{l}30 \\
25 \\
10\end{array}$ & $\begin{array}{l}5 \\
5 \\
5\end{array}$ & $\begin{array}{c}10 \\
15 \\
5\end{array}$ & $\dot{-}$ & - & $\begin{array}{l}\mathrm{P} \\
\mathrm{P}\end{array}$ & Fl. & 6.2 M.a. & $\begin{array}{l}\text { M } \\
\text { I } \\
\text { O }\end{array}$ \\
\hline $657 \mathrm{~B}-17 \mathrm{H}-4$ & \begin{tabular}{c|}
$134-135,5$ \\
$135,5-137$ \\
$138-139$
\end{tabular} & 12 & $\begin{array}{c}3 \\
3 \\
1,5\end{array}$ & $\begin{array}{c}9 \\
26 \\
78\end{array}$ & $\begin{array}{l}90 \\
90 \\
95\end{array}$ & $\begin{array}{l}80 \\
80 \\
80\end{array}$ & TA & - & $\mathrm{P}$ & $\mathrm{P}$ & $\begin{array}{c}10 \\
10 \\
4\end{array}$ & $\begin{array}{l}20 \\
18 \\
16\end{array}$ & \begin{tabular}{|c|}
0.5 \\
0.45 \\
0.5 \\
\end{tabular} & $i$ & $\begin{array}{l}-\bar{R} \\
\mathrm{R}\end{array}$ & : & $\begin{array}{l}10 \\
10 \\
5\end{array}$ & $\begin{array}{c}5 \\
5 \\
2,5 \\
\end{array}$ & $\begin{array}{c}5 \\
5 \\
2,5\end{array}$ & . & $\therefore$ & : & i & M.Eol. & $\begin{array}{l}\mathrm{a} \\
\mathrm{t} \\
\mathrm{c}\end{array}$ & C \\
\hline B & $15-16$ & & 33 & 66 & 55 & 40 & & & p & & & 12 & \begin{tabular}{|l|}
0.3 \\
\end{tabular} & $\mathrm{R}$ & $\mathrm{P}$ & & 45 & 10 & 30 & 5 & $=$ & & & & & \\
\hline
\end{tabular}

Note: Column 5 = percentage of siliciclastic grains in the sandy fraction. Column $6=$ quartz percentage of the siliciclastic sandy fraction and quartz grain exoscopic features. "eol." = eolian, "fluv." = fluvial,

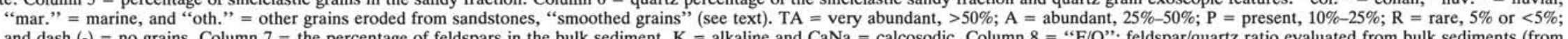
and dash $(-)=$ no grains. Column $7=$ the percentage of feldspars in the bulk sediment. $\mathrm{K}=$ alkaline and $\mathrm{CaNa}=$ calcosodic. Column $8=$ " $\mathrm{F} / \mathrm{Q}$ ": feldspar/quartz ratio evaluated from bulk sediments (from X-ray diffractometry). Column $12=$ "Biog. (\%)": percentage of biogenic particles in the sandy fraction (sum of Columns $13-18)$. Column $13=$ " "pl. F.": planktonic foraminifers. Column 14 . "s.w.b.": shallow-water bioclasts. Column $=<5 \%$, P (present) $=5 \%-10 \%$, and A (abundant) $=10 \%-20 \%$. Column $19=$ component assemblage (see explanation of abbreviations in "Discussion," this chapter). A dash indicates $0 \%$, and empty squares in the table indicate no data. 
Table 3. Clay minerals in turbidite sequences and associated pelagites at Holes 657A and 657B.

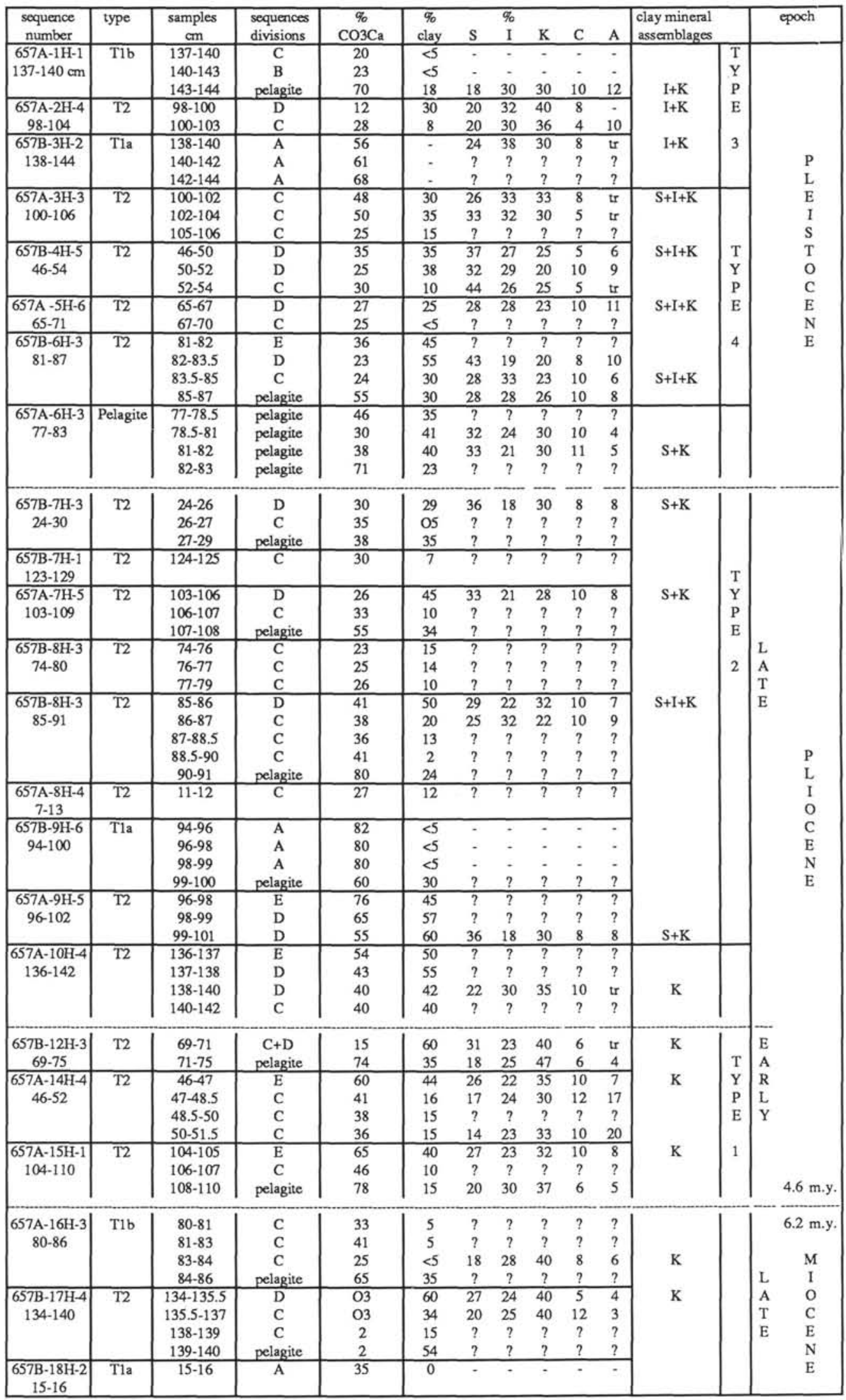

Note: $\mathrm{S}=$ smectite, $\mathrm{I}=$ illite, $\mathrm{K}=$ kaolinite, $\mathrm{C}=$ chlorite, and $\mathrm{A}=$ attapulgite $(\mathrm{tr} .=$ traces of attapulgite). 
4. Quartz grains with a long period of residence in marine environments are characterized by a clean smooth surface that exhibits chemically etched echelon pits on the flat part of the surface.

5. The category of "smooth and bright grains" consists of well-rounded, smoothed, and polished grains with a very clean surface. They show only very few impact features of aquatic origin. The history of this kind of grain is difficult to interpret. The general characteristics indicate a long period of evolution in an aquatic (marine or fluvial?) environment. Rare examples, however, bear a few crescent-shaped features of possibly eolian origin. Grains with crystalline forms suggestive of a volcanic or sedimentary authigenic origin are occasionally found.

6. Grains eroded from sandstones are characterized by a thick siliceous and/or calcareous coating that hides the former history of the grain.

Feldspar grains occur in all samples in low to high proportions of the bulk sediment (from $5 \%$ to $>30 \%$ ) and may have an iron coating like quartz. The feldspar/quartz ratio of the bulk sediment ranges from 0.25 to 1.6 , and calcosodic feldspars predominate with respect to alkaline feldspars. Micas and heavy minerals occur in only a few samples (5\% of the bulk sediment). They often represent a very low percentage of the sand fraction (from $1 \%$ to $<1 \%$ ). Iron oxide (hematite) is not a common constituent; it makes up $2 \%-3 \%$ of the sediment and seems to be of continental origin. Green grains (glauconite?) have been detected in only one sample and are considered to be reworked shelf sediment.

Authigenic components are mainly pyritic. These ubiquitous grains are rather common $(1 \%-2 \%)$, occasionally attaining higher proportions of 5\%-20\%, and are irregularly shaped. Sometimes, they consist of pyritized skeletal grains and, more rarely, of crystalline or framboidal forms.

Biogenic components generally represent only a minor part of the sand fraction in the basal division of turbidites. In some samples, nevertheless, they can account for $>50 \%$ to $95 \%$ of the fraction. Two groups of biogenic particles alternate in dominance: one is composed of pelagic foraminifers, the other one of shallow-water bioclasts. Benthic foraminifers, echinoid spines, siliceous components (sponge spicules, diatoms, and radiolarians), and scaphopods are less abundant.

The pelagic foraminifer group contains well-preserved tests of Globulina, Globorotalia, and Globigerina, with the last genus being most dominant. The foraminifers are associated with shell fragments.

The shallow-water bioclast group consists of coarsegrained shell debris belonging to benthic organisms (Plates $5 \mathrm{~A}, 5 \mathrm{~B}, 5 \mathrm{C}$, and 5D). Their size ranges from $100 \mu \mathrm{m}$ to over 3 $\mathrm{mm}$. Many of these clasts are dark gray. They have been grouped into two families depending on grain shape: clasts with well-rounded edges or fresh shell debris with sharp angles. The latter are only rarely observed. Observations under the binocular microscope (shape and state of preservation) and thin-section analyses for shell microstructures show that these grains are derived from pelecypod shells associated with balanid, gastropod, echinoid, and algal debris and benthic shallow-water foraminifers. There are also many fine unidentified bioclasts and occasional oöids. The coarsest particles are strongly corroded by microperforations of boring gastropods and algae. In thin sections, some of the finest bioclastic particles appear to be single rectangular crystals of calcitic prismatic structure belonging to molluscan shells.

\section{Clay Mineral Assemblages}

Clay mineral assemblages (Table 3) are dominated by abundant smectite, illite, and kaolinite (around $80 \%-90 \%$ altogether) with minor chlorite (around 5\%-10\%) and palygorskite $(<10 \%$, except for one turbidite sequence with $20 \%)$.

These minerals are associated with quartz and feldspar grains in the clay-sized fraction. Major variations in clay mineral proportions were observed between pelagic and turbiditic deposits, between turbiditic sequences of different ages, and, within one sequence, between the different facies members.

We identified four types of clay assemblages:

1. Predominantly kaolinite $(30 \%-47 \%)$, with lower proportions of illite $(20 \%-33 \%)$, and still less abundant smectite (14\%-31\%) (Table 3, Sections 108-657A-10H, 108-657A-14H, $108-657 \mathrm{~A}-15 \mathrm{H}, 108-657 \mathrm{~A}-16 \mathrm{H}, 108-657 \mathrm{~B}-12 \mathrm{H}$, and $108-657 \mathrm{~B}-$ 17H).

2. Predominantly smectite $(25 \%-36 \%)$ and kaolinite $(28 \%-$ $30 \%$ ), with a lower content of illite $(18 \%-24 \%)$ (Table 3, Sections 108-657A-6H, 108-657A-7H, 108-657A-9H, and 108657B-7H-3).

3. Predominantly illite $(30 \%-38 \%)$ and kaolinite $(30 \%-$ $40 \%$ ) and smaller proportions of smectite (18\%-24\%) (Table 3, Sections 108-657A-1H, 108-657A-2H, and 108-657B-3H).

4. Miscellaneous assemblages with dominant smectite $(26 \%-44 \%)$ and important variations between samples of the same sequence (illite: 19\%-33\%, kaolinite: 20\%-33\%) (Table 3 . Sections 108-657A-3H, 108-657A-5H, 108-657B-4H, and 108-657B-6H, and Sample 108-657B-8H-3, 85-87 cm).

The distribution of these assemblages throughout the Neogene turbidites shows that there is no particular correlation with specific types of turbidite sequences and assemblages of sand components: sequences of the same type and with the same components may contain different clay mineral assemblages (Table 3 ).

The assemblages are not as well defined and indicative as those observed in eolian dust collections and in modern and ancient marine dust sediments along the northwest African margin (Chester et al., 1972; Aston et al., 1973; Chamley et al., 1977; Chamley and Giroud d'Argoud, 1979; Lange, 1982; Melières, 1978; Sarnthein et al., 1982; Stein, 1985a). They are, in fact, the result of a mixture of clays from different sources on the continental margin, the composition of which is probably controlled by varying climatic and weathering conditions.

The results presented in the publications cited above demonstrate that clay assemblages with dominating kaolinite may indicate a south Saharan sediment source and probably a prolonged antecedent regime of monsoonal rain seasons. Conversely, illite-rich assemblages could witness the influence of a northwest Saharan sediment source and the existence of more arid conditions related to a dominant regime of northerly trade winds. Smectites are rather ubiquitous in North Africa, with an increasing abundance in the southern Sahara and in the sediment discharge of the Senegal River (Sarnthein et al., 1982). Finally, palygorskite might be reworked from Eocene continental deposits (Millot, 1964; Timofeev et al., 1978).

\section{DISCUSSION}

\section{Environmental Significance of Turbidites}

Based on structural, textural, and compositional data, we tried to evaluate the paleoenvironmental record of turbidite sequences; in particular, variations in the origin of sediments, in African continental climate, in the sea level, and in other changes of the ocean.

On a passive margin such as that off Senegal, the turbiditic sediments can be derived from both fluvial and desert sediment sources. In both cases, further sediment fractions are added during long-shore transport on the shelf and from the 
reworking pelagic deposits in canyons on the slope. Even in the case of a single source, the turbidite composition is modified during transport on the deep-sea floor by the addition of pelagic sediments as a result of more proximal or distal deposition and of the speed of the current. Hence, an interpretation of the origin of components from different turbidites must also consider the mean grain size of the pertinent sediment assemblages. We were able to distinguish three major categories of these turbidite assemblages.

\section{Eolian-Sand Turbidites}

This turbidite category (Table 2, Col. 19, "Eol."' component assemblage) is characterized by the occurrence of abundant quartz, shallow-water bioclasts (Plates 2C and 6A), small amounts of oöids, heavy minerals, iron grains, and various other accessory biogenic components (e.g., shallow-water benthic foraminifers) (Ruddiman, Sarnthein, et al., 1988).

The quartz fraction has a predominant proportion of frosted grains from dune sands (from $25 \%$ to $>60 \%$ ), showing a variably strong overprint due to transport in the marine environment. Quartz grains with marine surface evolution, rare grains eroded from sandstones (the possible remains from beach rock), and smooth and bright grains form the rest of the quartz fraction.

Hematite-coated quartz and feldspar are also present and more frequent than in fluvial-sand turbidites (see below; Plates $5 \mathrm{E}-5 \mathrm{H}$ and 6 ). The feldspar/quartz ratio of the bulk sediment is usually high (up to 1.6) with lower values only at the base of the cored section (108-657B-18H; Table 2). Silt and clay mineral contents are low or very low (except in eolian, fine-grained turbidites). Clay mineral assemblages vary between turbidites of different ages.

Such characteristics are observed in the coarse-grained, thick-bedded turbidite sequences (Type T1a), consisting of a massive well-sorted sand layer only (Bouma A-E sequence). Their characteristics largely match the eolian-sand turbidites as defined by Sarnthein and Diester-Haass (1977). Therefore, we interpreted the siliciclastic material as derived from dune sands and the bioclastic particles as originated from shore-line deposits. These turbidites mark continental margins where active desert dunes have migrated seaward up to the shelf edge because of dominant offshore winds and a lowered sea level, such as during glacial periods.

Furthermore, two fine-grained, thin-bedded turbidites (Type T2; Sections 108-657A-3H-3, 100-106 cm, and 108-657B-8H-3, $74-76 \mathrm{~cm}$ ) may originate from eolian dune sands, as indicated by a high content of frosted grains and hematite-stained grains associated with iron-oxide grains, heavy minerals, and abundant bioclasts, characteristic of a shore-line environment. We do not know whether the "distal character" of this turbidite (in the conventional classification scheme) is the result of a shift in the turbidite channel axis or a small quantity initially released by slump from the shelf.

\section{Fluvial-Sand Turbidites}

The component assemblage of fluvial-sand turbidites (Table 2, Col. 19, "Fl." component assemblage) differs from that of the eolian-sand turbidites in the absence of shallow-water bioclasts and by the predominance of quartz (Plates 6C and 6D). Quartz is composed of mixed angular to subangular, subrounded to well-rounded, and polished grains, $50 \%-90 \%$ of which have a clear fluvial origin, and the rest, a complex source history. There are grains with marine surface evolution $(5 \%-10 \%)$, reworked eolian grains $(0 \%-20 \%)$, smooth and bright grains, and grains eroded from sandstones.
We also encountered mica (muscovite and biotite) and rare plant debris. The feldspar/quartz ratio of the bulk sediment is low, ranging from 0.5 to 1.0 . The biogenic fraction consists of abundant pelagic foraminifers and accessory benthic foraminifers, echinoid clasts, and occasional diatoms from estuarine environments (Plate 4D). The absence or the presence of only very rare shallow-water bioclasts could be due to the fluvial mud flux that covers the shelf and dilutes shell sediments, as shown by modern shelf sediments off Senegal (Kiper, 1977; Pinson-Mouillot, 1980).

These constituent particles suggest a fluvial origin for the siliciclastic fraction. Parts of it may have mixed with reworked shore and shelf material, as shown by exoscopic studies of quartz grains. This facies only occurs in fine-grained, thinbedded turbidites (T2), conventionally considered as distal deposits with a C-D-E sequence. Since fluvial sediments indicate continental wetness, fluvial-sand turbidites were presumably emplaced under similar climatic conditions. By analogy with the late Quaternary (Sarnthein et al., 1982), they may be linked to interglacials and high sea-level phases in the south Saharan and Sahel Zones.

\section{Mixed Component Turbidites}

Several coarse-grained and fine-grained turbiditic layers contain a component assemblage with elements from both eolian-and fluvial-sand turbidites (Table 2, Col. 19, "M.,", "M.Fl.," "M.Eol.," and "M.Pel."' component assemblages). This assemblage is composed of low proportions of shallowwater bioclasts and of variable proportions of quartz and pelagic foraminifers as well as some accessory calcareous or siliceous debris (mixed assemblage). The siliciclastic grains cannot be clearly linked to any sediment source because the categories of quartz vary strongly.

We observed grains eroded from sandstones and grains with eolian surface characteristics next to grains with fluvial characteristics, both of them reworked in marine environments. Typical grains of eolian or fluvial origin are rare; likewise, smooth and bright grains. The origin of the sediment is obscured even more by an abundance of pelagic biogenic particles. The siliciclastic sand fraction is generally fine and very small, and its components reflect the impact of marine transport processes rather than specific continental sources.

Four mixed-particle assemblages were tentatively distinguished, the interpretation of which, however, is largely speculative (Table 2).

1. Mixed (M.): If eolian or fluvial source material markers are absent and, likewise, any other genetic markers, the sediments from any primary continental source may have been modified by prolonged long-shore transport or gravity currents by the addition of somewhat reworked shallow-water biogenic and siliciclastic and/or pelagic particles. No particular source environment can be inferred.

2. Mixed fluvial (M.Fl.): Some "mixed assemblages" with a low feldspar/quartz ratio do not contain significant amounts of frosted grains and stained quartz or feldspars nor any grain-size evidence of eolian dune origin. They do contain, however, small quantities of mica and/or plant debris and moreover, some exoscopic evidence of fluvial grain surfaces. Different grain-size spectra permit a further subdivision into proximal deposits (T1b sequence) and distal deposits (T2 sequence).

3. Mixed eolian (M.Eol.): In samples where shallow-water bioclasts are present in the sand fraction $(10 \%-15 \%)$, where some siliciclastic grains show eolian characteristics, and 
where a few heavy minerals and/or iron-oxide grains are present, we infer an eolian dune origin.

4. Mixed Pelagic (M.Pel.): Where the mixed assemblage is mostly composed of pelagic foraminifers $(70 \%-80 \%)$ occurring in fine-grained, thin-bedded turbidites, we assume a turbidite source on the continental slope, possibly released by slumps, similar to the interpretations for Site 658 (Ruddiman, Sarnthein, et al., 1988).

\section{Stratigraphic Distribution of Turbidites and Evolution of Sedimentary Source Environments during the Neogene}

Turbidites are generally frequent on the north Mauritanian continental margin throughout the late Neogene. Based on Holes $657 \mathrm{~A}$ and $657 \mathrm{~B}$, where no important removal of the sediment succession occurred during the slumps' deposition, phases of pelagic cyclic sedimentation undisturbed by turbidites were short and only lasted from 100 to 700 k.y. (Fig. 2). At Hole 657B, where turbidite layers are encountered more frequently, their frequency has strongly varied throughout the late Neogene (Fig. 2). It was infrequent during the Tortonian (about 3 turbidites per $1 \mathrm{~m} . \mathrm{y}$. .).

During the early Pliocene, the frequency increases to about 15 turbidites per $1 \mathrm{~m} . \mathrm{y}$. After $3.8 \mathrm{Ma}$, just on top of a megaslump, turbidites were infrequent until about $2.3 \mathrm{Ma}$ (i.e., the lowermost late Pliocene). Later on, the frequency again increases until the early Pleistocene, with about 34 turbidites per 1.6 m.y. After about $0.7 \mathrm{Ma}$, just after a double megaslump, turbidites were scarcer during the late Pleistocene, with only 7 or 8 events per $0.7 \mathrm{~m} . \mathrm{y}$. During the turbidite-rich periods, the turbidite events occurred every $25-40$ k.y.

Because we studied only one borehole, the turbidite frequency variations could be induced by several factors: climatic changes as well as geographic location of the sediment sources, and variations in slope morphology or downslope gravity-flow routes. Nevertheless, in the following sections, we assume that they may be considered as mainly related to the climatic conditions on the continent and to the concomitant modifications in terrigenous supplies (source and rate). But additional evidence will be required from the pelagic units between the turbidites to corroborate our results. The possible role of the other factors will be examined in the conclusion to this paper.

Based on the stratigraphy of turbidite characteristics and variations (Table 3), we were able to reconstruct the following history of the Neogene sediments.

\section{Prior to 6.2 Ma}

Turbidite events were infrequent prior to $6.2 \mathrm{Ma}$ (the base of a hiatus), with only about seven events for a period that lasted more than $2.5 \mathrm{~m}$.y. and had a wide facies diversity.

The first, oldest turbidite (Table 3, Sections 108-657A19X-1, 108-657A-19X-2, 108-657A-19X-3, and 108-657A-19X$\mathrm{CC}$ ) is more than $350 \mathrm{~cm}$ thick and contains eolian dune material, which suggests a desert climate on the continent in the late Tortonian about $8.5 \mathrm{Ma}$ ago. Later on, a turbidite with a mixed component assemblage records eolian sediment sources (T2 sequence, Section 108-657B-17H-4, 134-140 cm, mixed eolian) at about $6.7 \mathrm{Ma}$. The presence of such an arid climate is not consistent with previous studies that show a fairly constant high sea level, reduced or absent north Saharan trade winds, and a tropical climate during the late Tortonian (Michel, 1973; Sarnthein et al., 1982; Haq et al., 1987).

Just below the hiatus, before $6.2 \mathrm{Ma}$, fluvial sediment sources are recorded by a T1b sequence (Section 108-657A$16 \mathrm{H}-3,80-86 \mathrm{~cm})$. Thus, the marked sea-level drop and "cool" events at the end of the Miocene and other records about arid to semiarid climate and major Messinian glaciations (Kennett, 1982; Sarnthein et al., 1982; Stein, 1985a) has not been documented by turbidite deposition and could take place during the 6.2-4.6 Ma hiatus.

Clay minerals with predominant kaolinite (Type 1 assemblage) support the assumption of a south Saharan sediment source. The low feldspar/quartz ratio observed in both eolianand fluvial-sand turbidites suggests a strong alteration of crystalline rocks on the continent as a result of a long-lasting antecedent humid climate.

\section{The Early Pliocene}

The early Pliocene was characterized by frequent thinbedded, fine-grained turbidites ( $15 \mathrm{~T} 2$ sequences per $\sim 1 \mathrm{~m} . \mathrm{y}$.) that contain only mixed components (category $\mathrm{M}$ ). The early/ late Pliocene boundary is marked by a striking megaslump of pelagic sediment cycles. The absence of thick-bedded turbidites containing eolian material from 4.6 to $3.8 \mathrm{Ma}$ ago can be regarded as evidence that nondesert conditions prevailed on the continent during the early Pliocene.

Nevertheless, the feldspar/quartz ratio was slightly higher than prior to this time and remained so throughout the late Pliocene and Quaternary. Moreover, frequent thin-bedded turbidites suggest the presence of a strong and largely continuous continental sediment input that is more consistent with deltaic than eolian discharge (i.e., with a humid climate). This interpretation fits very well with a constant high sea level during this period (Haq et al., 1987). Clay minerals are supplied from sources similar to those of the late Miocene.

\section{The Late Pliocene}

During the late Pliocene, turbidites were less frequent (about $16 \mathrm{~T} 2$ or T1a sequences per $2 \mathrm{~m} . \mathrm{y}$.) and are scattered irregularly throughout the deposits. Their frequency is low during the beginning of the late Pliocene ( 3 T1 and 3 T2 turbidites per $\sim 1.5$ m.y., from about 3.8 to $2.3 \mathrm{Ma}$ ) and then increases toward the end of the late Pliocene ( $10 \mathrm{~T} 2$ sequences per $\sim 0.7 \mathrm{~m}$.y., from about 2.3 to $1.6 \mathrm{Ma}$ ).

The sand composition shows abundant eolian dune material or mixed sediments still enriched with eolian components (mixed eolian). Therefore, we assumed that a desert climate was established during this period and even more so around 2.6 Ma, when eolian coarse-grained turbidites were deposited (Section 108-657B-9H). Humid climatic conditions seem to return at the end of the Pliocene (about $1.9 \mathrm{Ma}$ ago), as inferred from fluvial-sand turbidites and mixed assemblages with river-born material (mixed fluvial) in fine-grained turbidites (Section 108-657A-7H-5, 103-109 cm). These changes were already noted at DSDP Sites 367 and 397 (Sarnthein, 1978) and are consistent with the first occurrence of extensive glaciations on the northwestern hemisphere continents and a progressive climatic deterioration (Sarnthein et al., 1982; Stein, 1985b, 1986).

Various clay mineral assemblages occur, with a major change between Cores 108-657 A-10H and $-9 \mathrm{H}$, about $2.9 \mathrm{Ma}$ ago. Although Core 108-657A-10H shows a Type 1 assemblage with predominant kaolinite such as in the underlying sediment pile, a turbidite (Section 108-657A-9H-6, 94-100 $\mathrm{cm}$ ) and adjacent pelagic sediments (Section 108-657A-9H-5, $95-102 \mathrm{~cm}$ ) display a Type 2 assemblage with abundant smectite and kaolinite. The increase in smectite may suggest an increase in the Sahara, in the deflation and/or formation of calichisoils characteristically enriched in smectite.

\section{The Pleistocene}

The Pleistocene is characterized by a high frequency of turbidites, with 32 events per 1.6 m.y. However, the fre- 


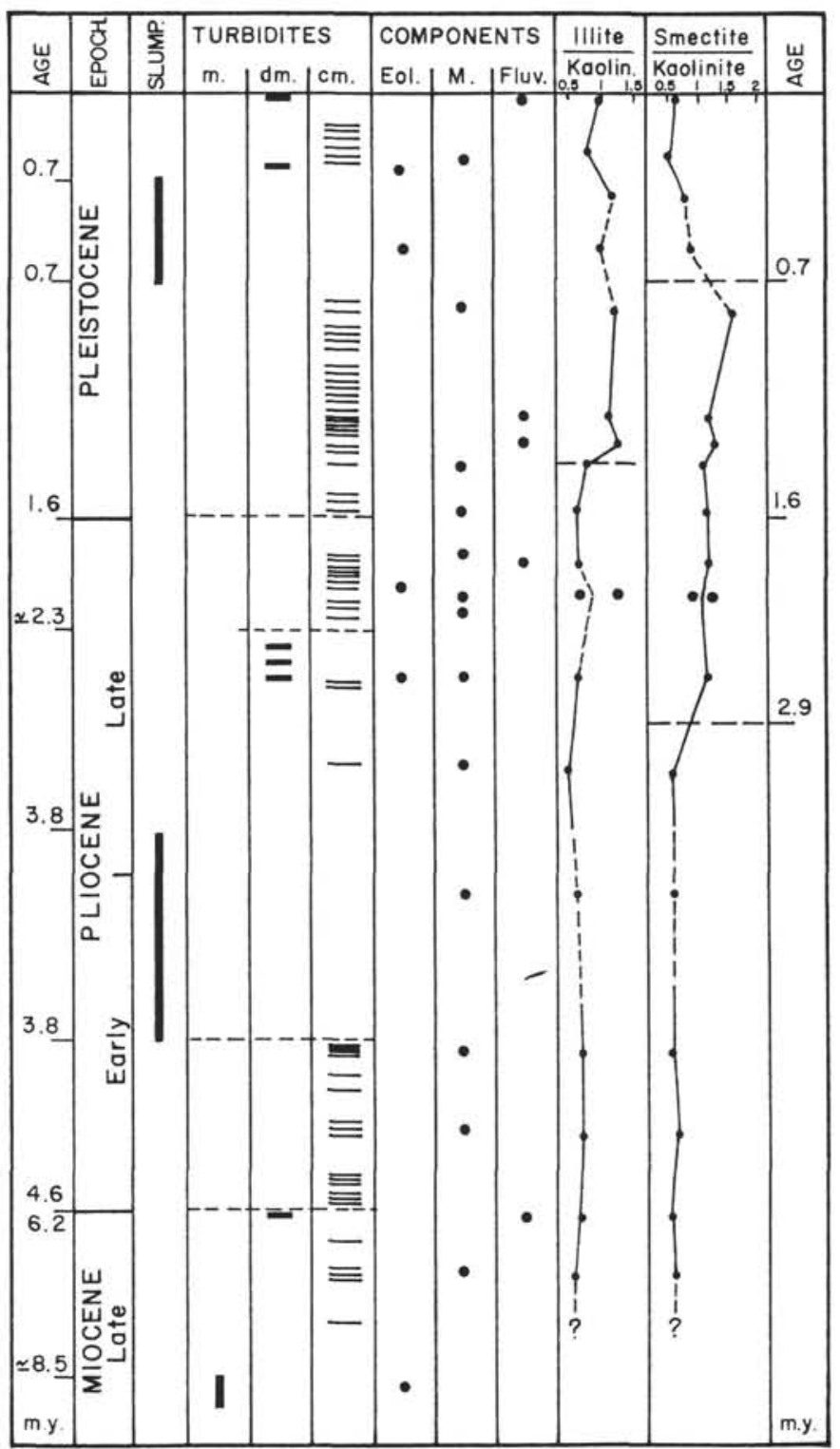

Figure 5. Schematic stratigraphic distribution of turbidite characteristics throughout the Neogene deposits. The clay mineral data only is from samples plotted on Table 3.

quency decreases during the last $0.7 \mathrm{~m} . \mathrm{y}$. , subsequent to the rapid deposition of two slumps, one originating from the shelf, the other one from the lower slope (Günther, 1988). From 1.6 to $0.7 \mathrm{Ma}$, turbidites were fine grained and thin bedded ( $24 \mathrm{~T} 2$ sequences) and distanced fairly regularly. Major characteristics were mixed and fluvial component assemblages that witness little continental aridity.

After 0.7 Ma, two thick-bedded, coarse-grained turbidites (T1a and T1b sequences) are composed of either eolian dune sand or mixed sediment (mixed fluvial). Furthermore, a number of thin-bedded, fine-grained turbidites (6 T2 sequences) with mixed sediment (mixed eolian) now suggest prevailing aridity. More frequent siliceous biogenic particles record an increase in coastal upwelling off Cap Blanc during this period (Sarnthein et al., this vol.; Stein, 1985b; Stein et al., this vol.).

Clay minerals vary strongly throughout this period, with miscellaneous assemblages (Type 4) in the lower part and predominant illite assemblages (Type 3 ) in the uppermost section $(108-657 \mathrm{~A}-1 \mathrm{H}$ and $-2 \mathrm{H})$, which indicate a northwest Saharan source. In summary, the late Pleistocene seems to have been marked by alternating climatic cycles on land, with a strong increase in the number of arid episodes compared with the early Pleistocene.

\section{CONCLUSIONS}

At Site 657, numerous siliciclastic turbidites are interbedded in pelagic Neogene deposits. Sedimentological analyses enable the following conclusions (Fig. 5).

1. The frequency of turbidites has varied throughout the late Neogene. The lowest frequency is observed during the Tortonian ( 7 turbidites per $>2.5 \mathrm{~m} . \mathrm{y}$.), and the highest during the early Pliocene ( 15 turbidites per $1 \mathrm{~m} . \mathrm{y}$.$) and the latest$ Pliocene-early Pleistocene (34 turbidites per 1.6 m.y.).

2. The irregular occurrence of turbidites throughout the Neogene excludes the possibility of direct time control by orbital forcing. Only on shorter time scales (i.e., below and above the Pliocene-Pleistocene boundary and during the late Pleistocene) do turbidite frequencies occur on the order of 1 turbidite/25 k.y. and 1 turbidite/100 k.y., respectively, and, hence, turbidite frequencies might resemble climatic cycle frequencies and could be controlled by sea-level fluctuations. The long-term frequency variations may be related to changes in continental sediment inputs that might have been weak in the late Miocene and at the base of the late Pliocene and slightly more abundant in the late Pleistocene and that might have culminated during the early Pliocene and the latest Pliocene-early Pleistocene. In addition, the fact that the turbidite frequency strongly decreases during the base of the late Pliocene and the late Pleistocene, just after the megaslump deposition, suggests a possible turbidite frequency control by variations of the continental slope morphology.

3. The grain size, component, and sequence composition of turbidites led to the differentiation of thick-bedded and coarsegrained vs. thin-bedded and fine-grained turbidites, the component assemblages of which vary in a characteristic way: (1) "eolian-sand turbidites" contain abundant wind-transported siliciclastic sand grains and shallow-water bioclasts and mainly match the thick layers; (2) "fluvial-sand turbidites" are composed of river-born material and are mostly linked to the thin layers; and (3) other turbidites contain mixed component assemblages with a dominance of either eolian or fluvial input.

4. The stratigraphic distribution of different types of turbidites reveals a systematic variation in sediment sources and the governing climatic conditions on the continent: (1) Prior to 6.2 Ma (late Tortonian), turbidites reflect conditions of a humid climate following a desert climate, especially at about 8.5 and 6.7 $\mathrm{Ma}$. The presence of such conditions is not consistent with the classical results of previous works (Sarnthein et al., 1982; Kennett, 1982), that is, a high sea level with a tropical climate during the late Tortonian and a sea-level drop and arid conditions during the terminal Miocene event. (2) During the early Pliocene, the absence of typical eolian-sand turbidites and the presence of very frequent fine-grained turbidites with mixed component assemblages support the assumption of humid, subtropical conditions on the African continent (Sarnthein et al., 1982). (3) The late Pliocene is characterized by frequent coarse-grained and fine-grained turbidites, which are made up of eolian dune sands and mixed component assemblages at the beginning and fluvial sediments at the end of the Pliocene. Hence, the turbidites document an intense desertification in the Sahel Zone at about 2.6 Ma and alternating humid and dry phases after 2.3 Ma. These changes are consistent with the well-known climatic deterioration related to the formation of Northern Hemisphere ice sheets during this period. (4) Pleistocene turbidites with river-born sediments during the early Pleistocene and alternating eolian and 
fluvial sands during the late Pleistocene show a progressive aridification of the Saharan climate, especially after $0.7 \mathrm{Ma}$.

5. Clay mineral assemblages vary throughout the Neogene turbiditic deposits. A predominant kaolinite assemblage occurs during the late Miocene and the early Pliocene; after 2.9 $\mathrm{Ma}$, the kaolinite percentage decreases and a predominant smectite-kaolinite assemblage occurs during the late Pliocene. These two assemblages support the assumption of a south Saharan sediment source. Pleistocene deposits show a miscellaneous clay assemblage until $0.7 \mathrm{Ma}$; thereafter, an increase of illite records a north Saharan sediment source during the last 0.7 m.y.

\section{REFERENCES}

Aston, S. R., Chester, R., Johnson, L. R., and Padgham, R. C., 1973. Eolian dust from the lower atmosphere of the eastern Atlantic and Indian Oceans, China Sea and Sea of Japan. Mar. Geol., 14:15-28.

Berger, W. H., and von Rad, U., 1972. Cretaceous and Cenozoic sediments from the Atlantic Ocean. In Hayes, D. E., Pimm. A. C., et al., Init. Repts. DSDP, 14: Washington (U.S. Govt. Printing Office), 787-954.

Bouma, A. H., 1962. Sedimentology of Some Flysch Deposits: Amsterdam (Elsevier).

Chamley, H., Diester-Haass, L., and Lange, H., 1977. Terrigenous material in East Atlantic sediment cores as an indicator of NW African climates. Meteor Forschungsergeb., Reihe C, 38:44-59.

Chamley, H., and Giroud d'Argoud, G., 1979. Clay mineralogy of Site 397, south of Canary Islands (DSDP Leg 47A). In von Rad, U., Ryan, W.B.F., et al., Init. Repts. DSDP, 47, Pt. 1: Washington (U.S. Govt. Printing Office), 595-602.

Chester, R., Elderfield, H., Griffin, J. J., Johnson, L. R., and Padgham, R. C., 1972. Eolian dust along the eastern margins of the Atlantic Ocean. Mar. Geol., 13:916.

Cremer, M., 1983. Approches sédimentologiques et géophysiques des accumulations turbiditiques [Ph.D. thesis]. Univ. Bordeaux I, France.

Cremer, M., and Stow, D., 1986. Sedimentary structures of finegrained sediments from the Mississippi fan: thin-section analyses. In Bouma, A. H., Coleman, J. M., et al., Init. Repts. DSDP, 96: Washington (U.S. Govt. Printing Office), 519-532.

Faugères, J. C., Cremer, M., Gonthier, E., Noel, M., and Poutiers, J., 1984a. Late Quaternary calcareous clayey-silty muds in the Obock Trough (Gulf of Aden): hemipelagites or fine-grained turbidites? Geol. Soc. Spec. Publ. (London), 15:209-222.

Faugères, J. C., Gonthier, E., and Stow, D., 1984b. Contourite drift molded by deep Mediterranean outflow. Geology, 12:296-300.

Fritz, S. J., and Pilkey, O. H., 1975. Distinguishing bottom and turbidity current coarse layers on the continental rise. J. Sediment. Petrol., 45:57-62.

Gonthier, E., Faugères, J. C., and Stow, D., 1984. Contourite facies of the Faro Drift, Gulf of Cadix. Geol. Soc. Spec. Publ. (London), 15:275-292.

Günther, R., 1988. Rutschmassensediment und ihr möglichber ursprung am kontinentalhang vor NW Africa $\left(20^{\circ} \mathrm{N}\right)(\mathrm{ODP}$, Sites 657,658 ) [M.S. thesis]. Univ. Kiel, Federal Republic of Germany.

Haq, B. U., Hardenbol, J., and Vail, P. R., 1987. Chronology of fluctuating sea levels since the Triassic. Science, 235:1156-1167.

Hayes, D., Pimm, A. C., et al., 1972. Init. Repts. DSDP, 14: Washington (U.S. Govt. Printing Office), 157-248.

Jacobi, R., and Hayes, D., 1982. Bathymetry, microphysiography and reflectivity characteristics of the West African margin, between Sierra Leone and Mauritania. In von Rad, U., Hinz, K., Sarnthein, M., and Seibold, E. (Eds.), Geology of the Northwest African Continental Margin: Berlin-Heidelberg-New York (Springer-Verlag), 182-212.

Kennett, J., 1982. Marine Geology: New York (Prentice Hall).

Kiper, M., 1977. Sedimente und ihre umwelt in Senegal delta [M.S. thesis]. Univ. Kiel, Federal Republic of Germany.

Lange, H., 1982. Distribution of chlorite and kaolinite in eastern Atlantic sediments off North Africa. Sedimentology, 29:427-432.

Le Ribault, L., 1977. L'Exoscopie. Méthodes et Applications. Notes et mémoires, 12: Paris (Compagnie Française des Pétroles).
Melières, F., 1978. X-ray mineralogy studies, Leg 41, Deep Sea Drilling Project, eastern North Atlantic Ocean. In Lancelot, Y., Seibold, E., et al., Init. Repts. DSDP, 41: Washington (U.S. Govt. Printing Office), 1065-1086.

Michel, P., 1973. Les bassins des fleuves Sénégal et Gambie, étude géomorphologique. Mem. ORSTOM, 752.

Middleton, G. V., and Hampton, A. M., 1973. Sediment gravity flows: mechanics of flow and deposition. In Middleton, G. V., and Bouma, A. H. (Eds.), Turbidites and Deep Sedimentation. SEPM Short Course.

Millot, G., 1964. Geologie des Argiles: Paris (Masson).

Moyes, J., Duplantier, F., Duprat, J. C., Faugères, J. C., Pujol, C., Pujos-Lamy, A., and Tastet, J. P., 1979. Etude stratigraphique et sédimentologique. In Arnould, M., and Pelet, R. (Eds.), La Géochimie Organique des Sédiments Marins Profonds: Orgon III (Mauritanie, Sénégal, Iles du Cap Vert): Paris (CNRS), 121-213.

Mutti, E., and Ricci-Lucchi, F., 1974. La signification de certaines unités séquentielles dans les séries a turbidites. Bull. Soc. Geol. Fr., 26:577-582.

Normark, W. R., 1978. Fan valleys, channels and depositional lobes on modern submarine fans: characters of recognition of sandy turbidite environments. AAPG Bull., 62:912-931.

Pinson-Mouillot, J., 1980. Les environnements sédimentaires actuels et quaternaires du plateau continental Sénégalais [thesis]. Univ. Bordeaux 1, France.

Robert, C., 1982. Modalité de la sédimentation argileuse en relation avec l'histoire geologique de l'Atlantique Sud [thesis]. Marseille Univ., France.

Ruddiman, W., Sarnthein, M., et al., 1988. Proc. ODP, Sci. Results, 108: College Station, TX (Ocean Drilling Program).

Sarnthein, M., 1978. Neogene sand layers off northwest Africa: composition and source environment. In Lancelot, Y., Seibold, E., et al., Init. Repts. DSDP, Suppl. to $38,39,40$, and 41 : Washington (U.S. Govt. Printing Office), 939-959.

Sarnthein, M., and Diester-Haass, L., 1977. Eolian-sand turbidites. J. Sediment. Petrol., 47:868-890.

Sarnthein, M., Thiede, J., Pflaumann, U., Erlenkeuser, H., Fütterer, D., Koopmann, B., Lange, H., and Seibold, E., 1982. Atmospheric and oceanic circulation patterns off northwest Africa during the past 25 million years. In von Rad, U., Hinz, K., Sarnthein, M., and Seibold, E. (Eds.), Geology of the Northwest African Continental Margin: Berlin-Heidelberg-New York (SpringerVerlag), 545-603.

Stein, R., 1985a. The post Eocene sediment record of DSDP Site 366: implications for African climate and plate tectonic drift. Geol. Soc. Am., 163:305-315.

1985b. Late Neogene changes of paleoclimate and paleoproductivity off northwest Africa (DSDP 397). Paleogeogr., Paleoclimatol., Paleoecol., 49:47-59.

1986. Late Neogene evolution of paleoclimate and paleoceanic circulation in the Northern and Southern Hemisphere: a comparison. Geol. Rundsch., 75:125-138.

Stow, D., 1984. Turbiditic facies, associations, and sequences in the southeastern Angola Basin. In Hay, W., Sibuet, J. C., et al., Init. Repts. DSDP, 75: Washington (U.S. Govt. Printing Office), 785799.

Stow, D., and Piper, D., 1984. Fine-grained sediments: deep-water processes and facies. Geol. Soc. Spec. Publ. (London), 15.

Stow, D., and Shanmugam, G., 1980. Sequences of structures in fine-grained turbidites: comparison of recent deep-sea and ancient flysch sediments. J. Sediment. Geol., 25:23-42.

Timofeev, P. P., Eremeev, V. V., and Rateev, M. A., 1978. Palygorskite, sepiolite, and other clay minerals in Leg 41 oceanic sediments: mineralogy, facies, and genesis. In Lancelot, Y., Seibold, E., et al., Init. Repts. DSDP, 41: Washington (U.S. Govt. Printing Office), 1087-1101.

Walker, R. G., 1978. Deep water sandstone facies and ancient submarine fans: models for exploration for stratigraphic traps. $A A P G$ Bull., 62:932-966.

Date of initial receipt: 30 March 1988

Date of acceptance: 12 February 1989

Ms 108B-137 


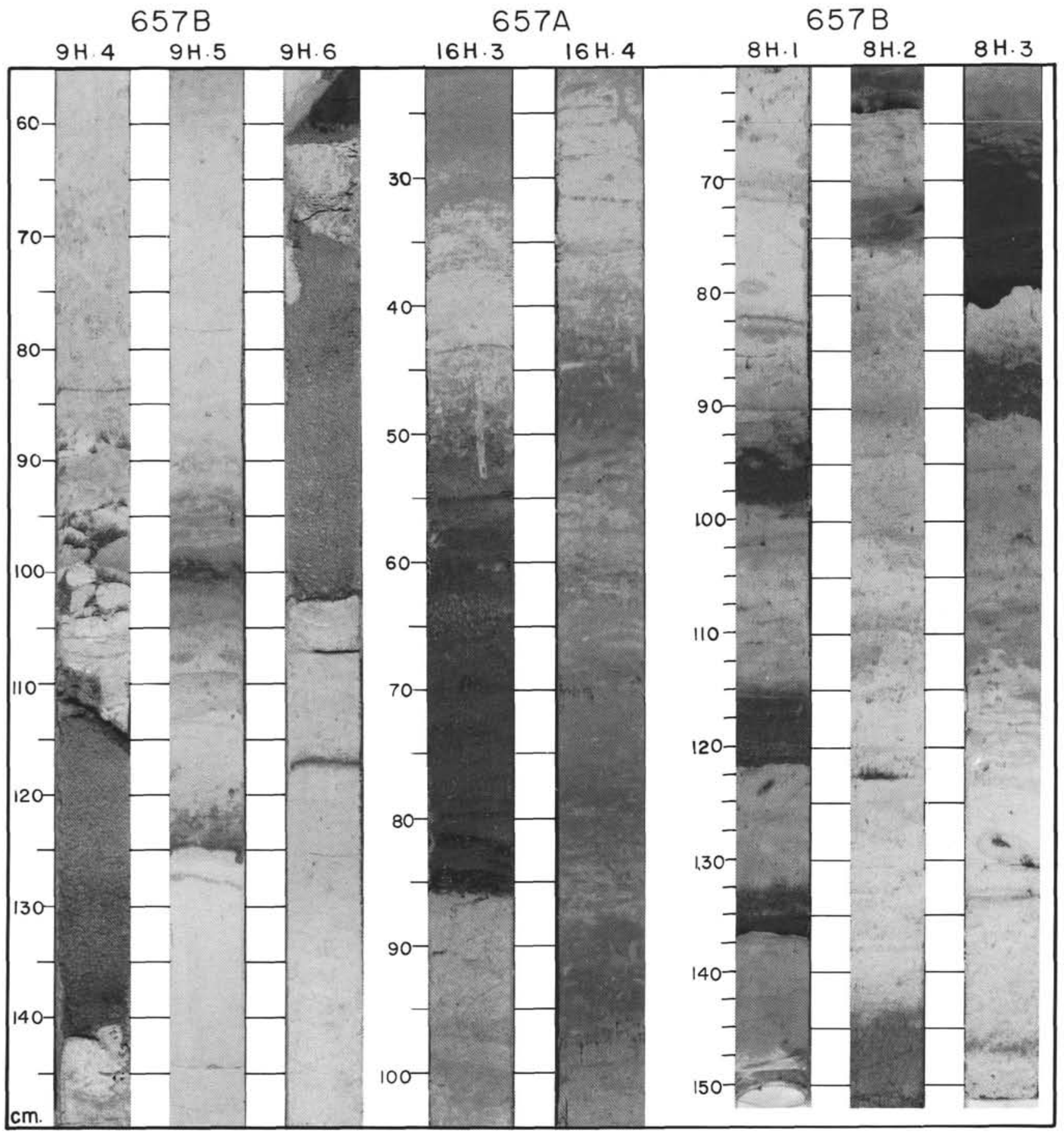

Plate 1. Turbidites interbedded with calcareous pelagic ooze. Sections 108-657B-9H-4, 108-657A-9H-6, and 108-657A-16H-3 display massive T1a sequences. Sections 108-657B-8H-1, 108-657B-8H-2, 108-657B-8H-3, and 108-657B-9H-5 show T2 sequences (dark layers). Section 108-657A-16H-4 consists of pelagic sediment cycles of light gray nannofossil ooze and yellowish brown silty nannofossil ooze. 
$657 A$

$657 B$

I H. I, 137_ $144 \mathrm{~cm}$.

$16 \mathrm{H} .3,8 \mathrm{O}_{-} 86 \mathrm{~cm}$.

$9 \mathrm{H} .6,94-100 \mathrm{~cm}$.

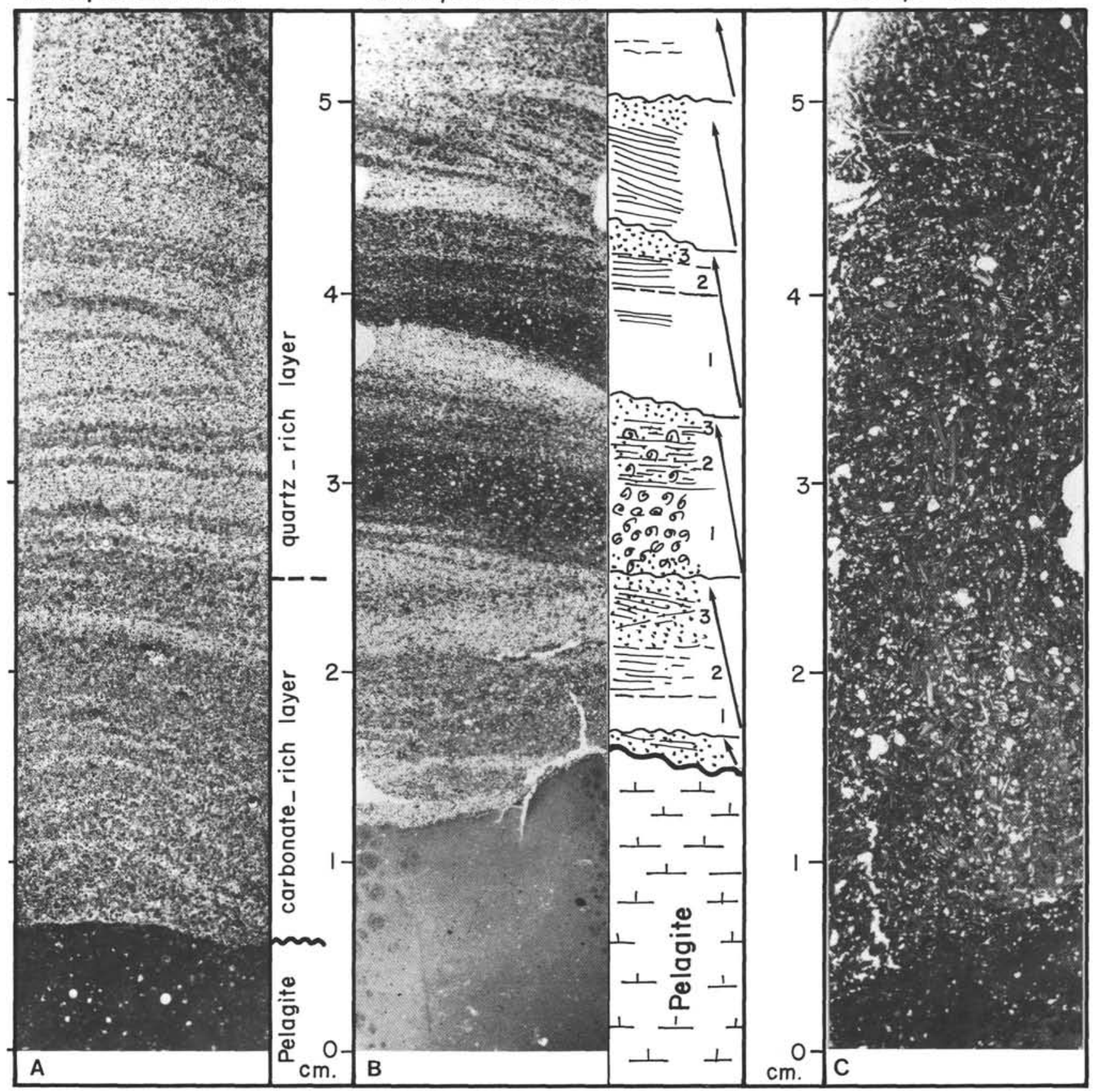

Plate 2. Microfacies and microstructures at the base of coarse-grained, thick-bedded turbidites (T1). A. Section 108-657A-1H-1, 137-144 cm, laminated T1b sequence. B. Section 108-657A-16H-3, 80-86 cm, T1b sequence with microsequences. $1=$ massive bioclast and foraminifer ooze; 2 = quartz-rich carbonate ooze with laminations; and 3 = silty-sandy quartz layer. C. Section 108-657B-9H-6, 94-100 cm, massive T1a sequence. 


\section{$657 \mathrm{~A}$}

$2 \mathrm{H} .4,98-104 \mathrm{~cm}$.

$8 \mathrm{H} .3,74 \_80 \mathrm{~cm}$.

$3 \mathrm{H} .3,100_{-} 106 \mathrm{~cm}$.

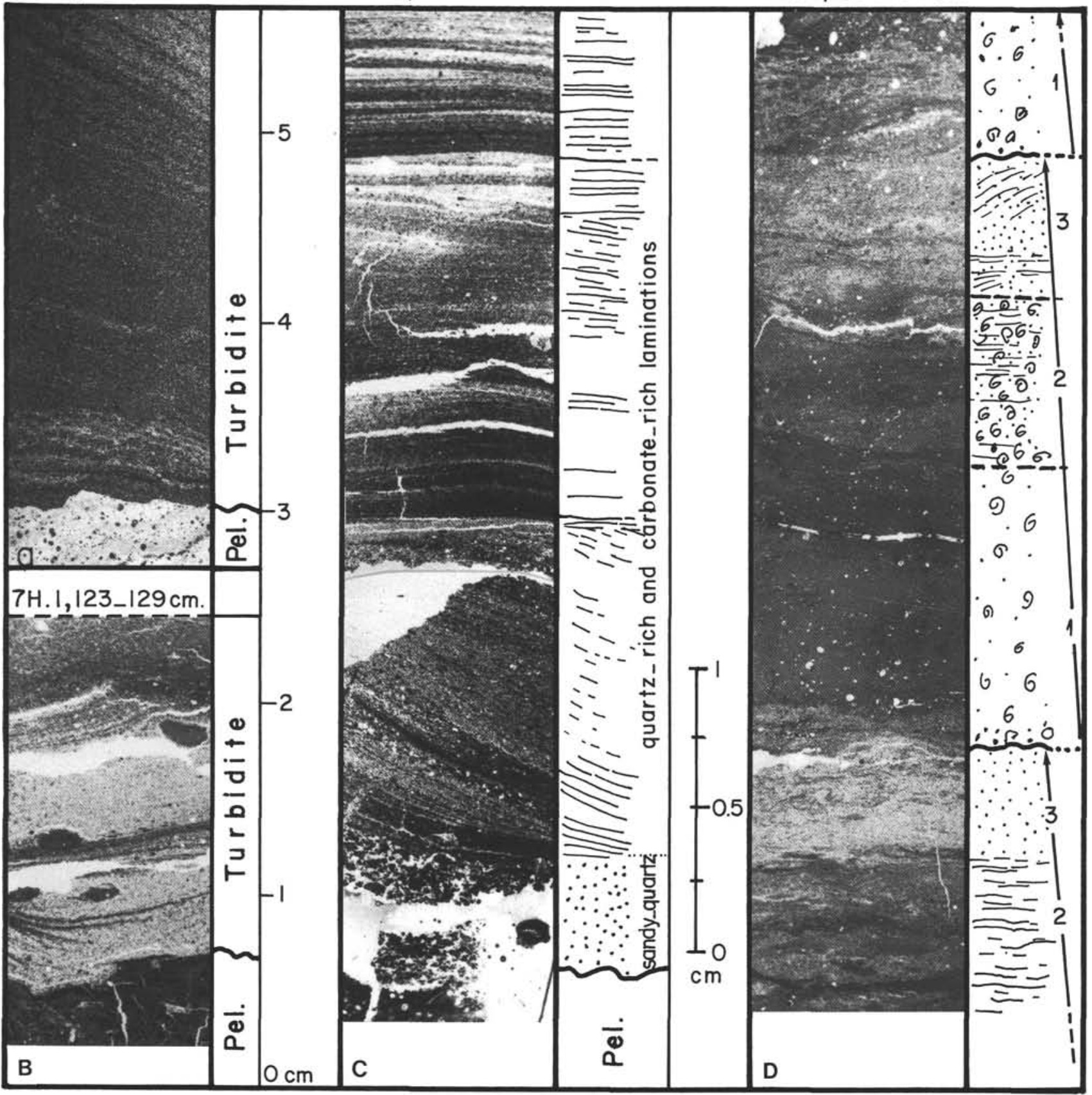

Plate 3. Microstructures in fine-grained, thin-bedded turbidites (T2). A. 108-657A-2H-4, 98-104 cm. B. Section 108-657A-7H-1, 123-129 cm. C. Section 108-657A-8H-3, 74-80 cm. D. Section 108-657A-3H-3, 100-106 cm, with microsequences at the base of the sequences (see Plate $2 \mathrm{~B}$ for the lithologic symbols). 

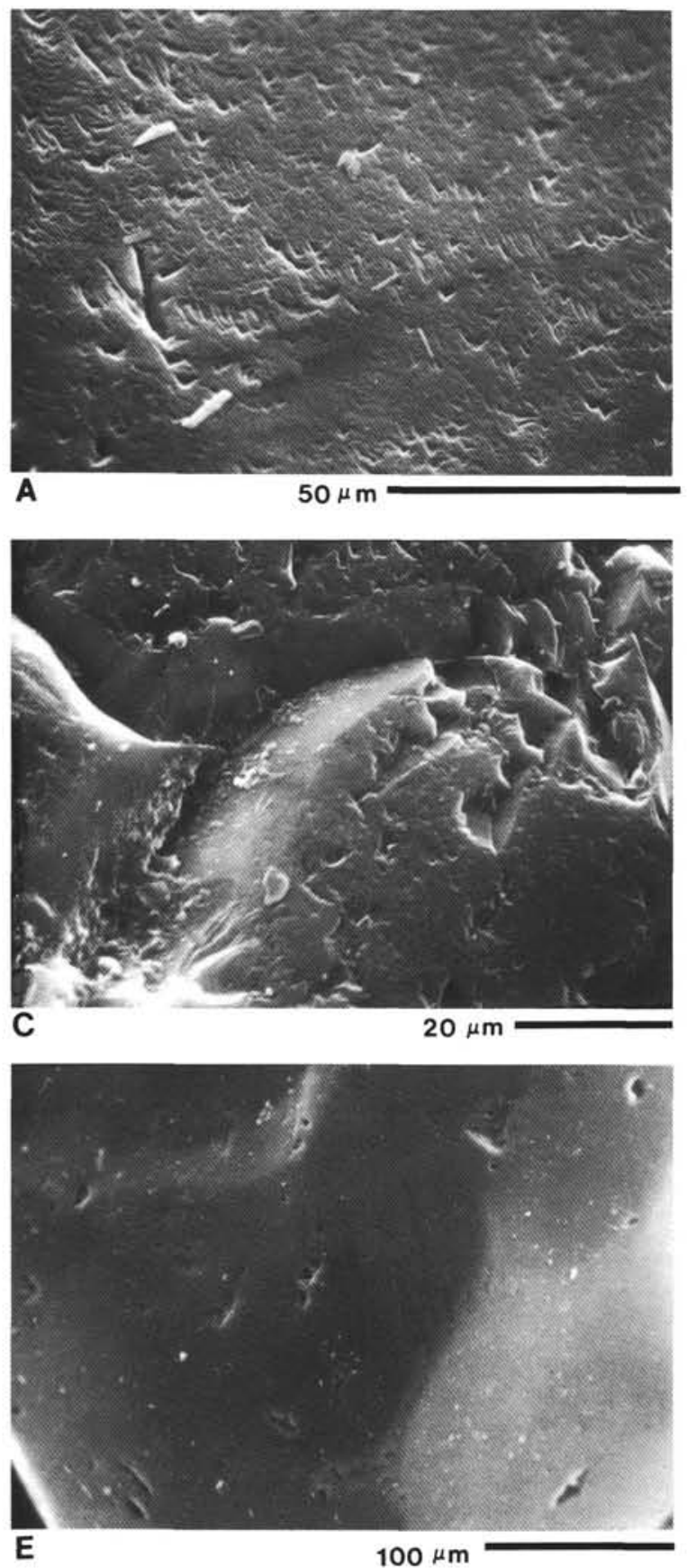
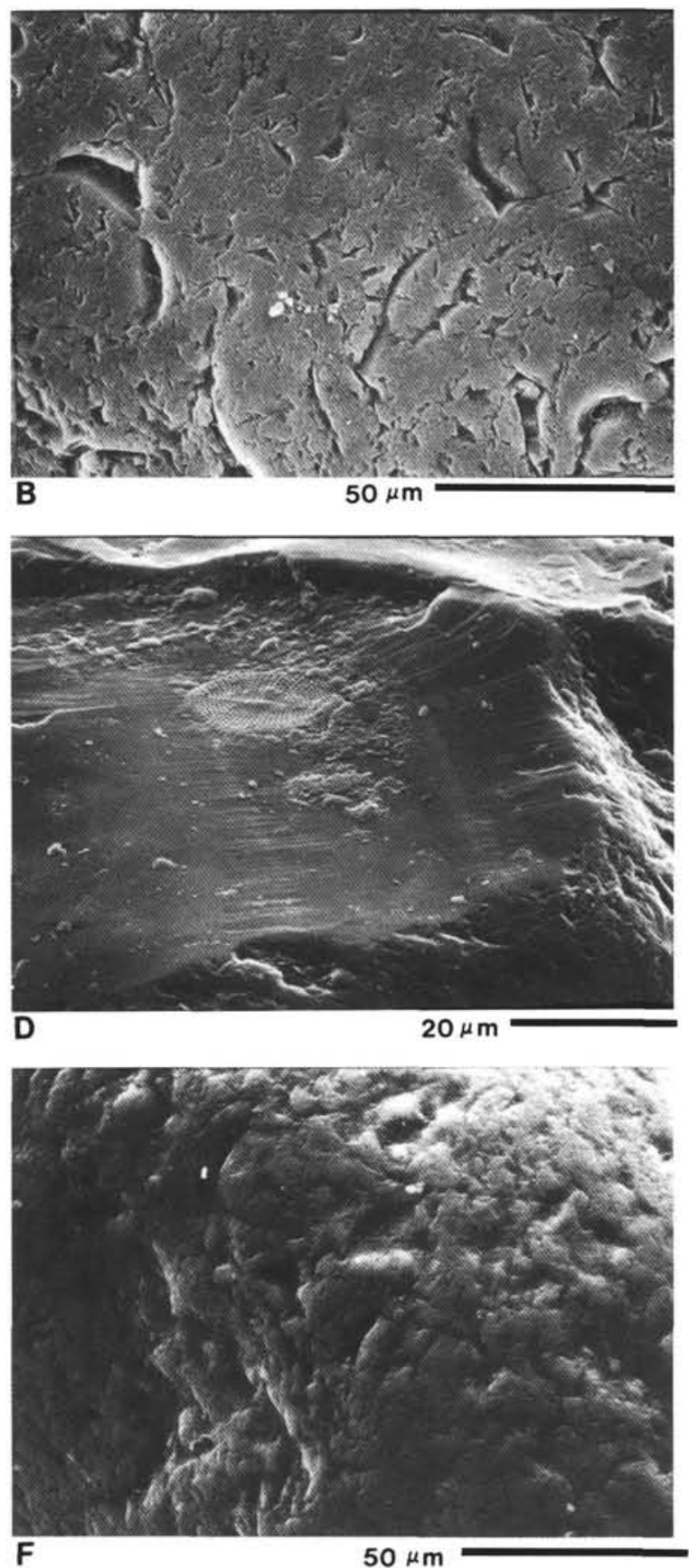

$50 \mu \mathrm{m}$

Plate 4. Exoscopic characters of quartz grain. A. Grain with prolonged evolution in marine environments (Sample 108-657A-1H-1, 140-143 cm). B. Reworked eolian grain (Sample 108-657A-3H-3, 100-102 cm). C. Recent eolian grain (Sample 108-657A-2H-4, 100-103 cm). D. Fluvial grain (Sample 108-657A-7H-5, 106-107 cm) with diatom cemented to surface (Cocconeis guarnerensis Grunou). E. "Smoothed grain" (Sample 108-657B-9H-6, 96-98 cm). F. Grain eroded from sandstones (Sample 108-657B-17H-4, 134-135.5 cm). 

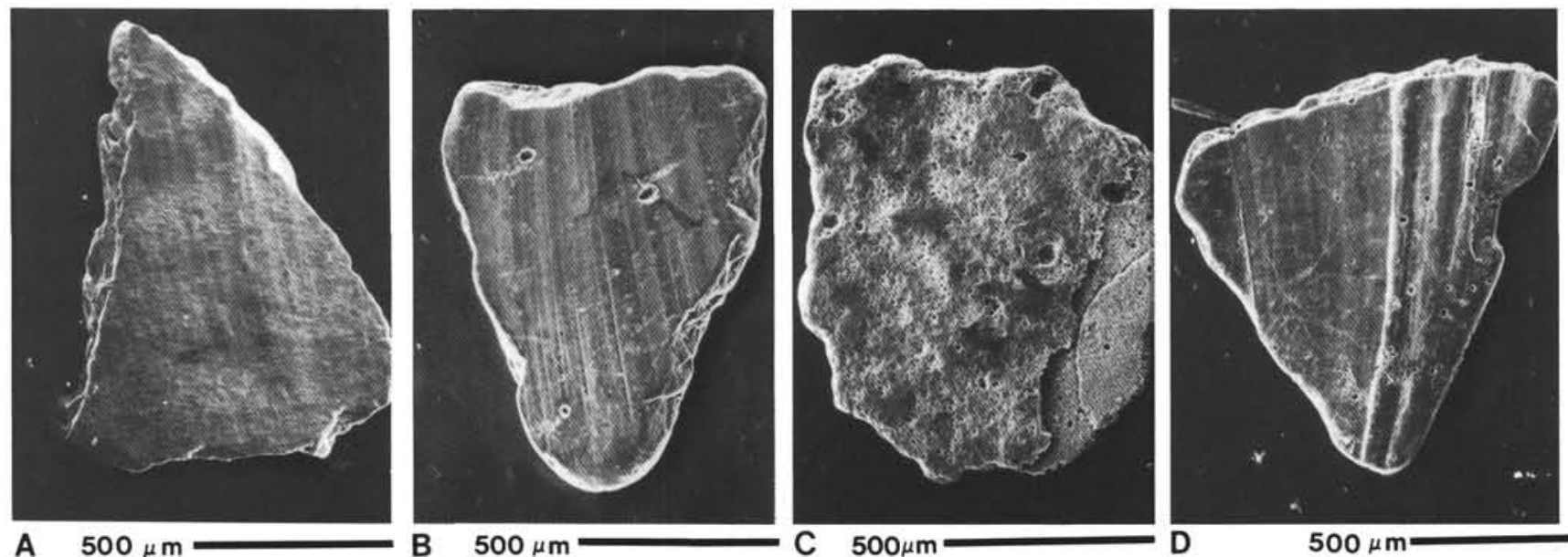

\section{A $500 \mu \mathrm{m}$}

\section{B $500 \mu \mathrm{m}$}
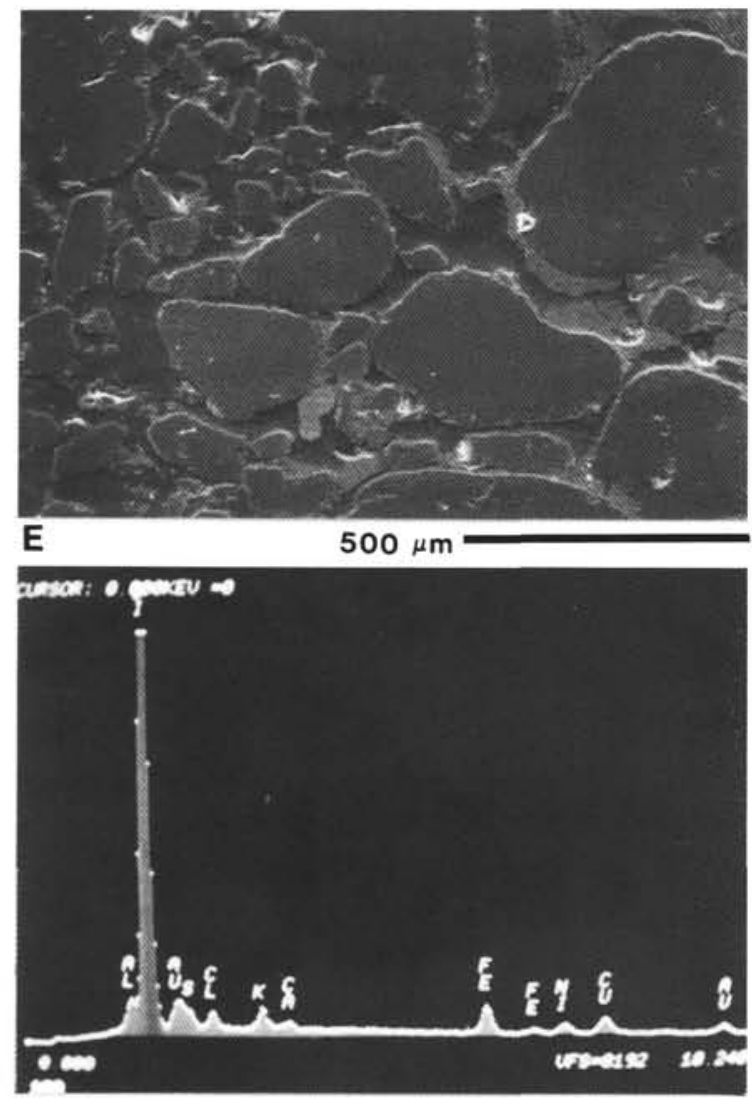

$\mathbf{F}$

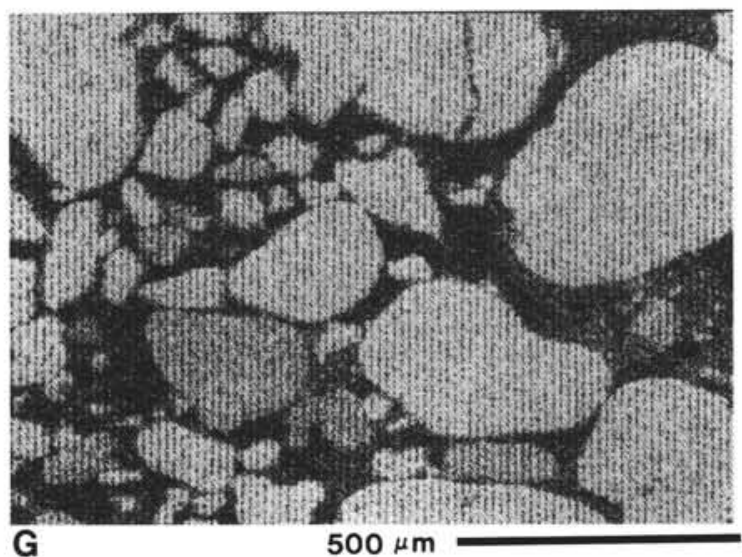

$500 \mu \mathrm{m}$

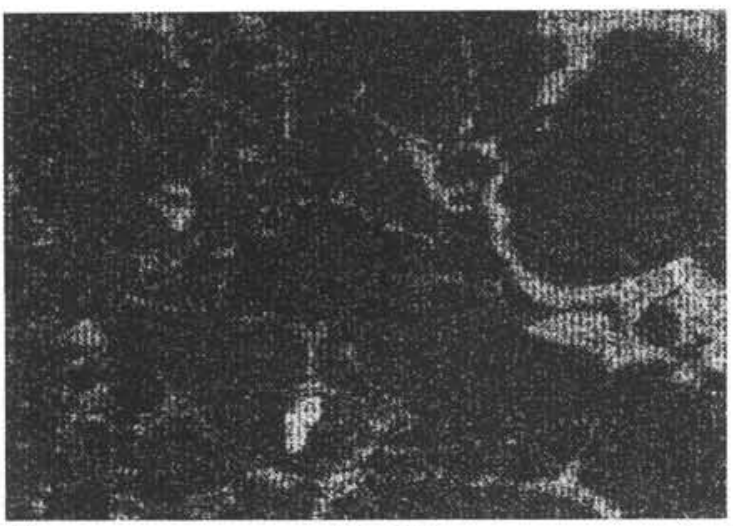

H

$500 \mu \mathrm{m}$

Plate 5. Different aspects of gray shallow-water bioclasts (Section 108-657B-3H-2, 138-140 cm). A. Bioclast with sharp angles. B. Well-rounded bioclast. C. Strongly corroded bioclast. D. Well-rounded bioclast from a pelecypod shell. Eolian assemblage components analyzed on an impregnated polished sediment slide by SEM (Sample 108-657B-17H-4, $138 \mathrm{~cm}$ ). E. Well-rounded grains. F. Global chemical composition (EDX). G. Silica distribution showing that nearly all the grains are quartz (X analysis). $\mathbf{H}$. Fe distribution showing that this element constitutes small grains and coatings around quartz grains ( $\mathrm{X}$ analysis). 


\section{J. C. FAUGÈRES ET AL.}

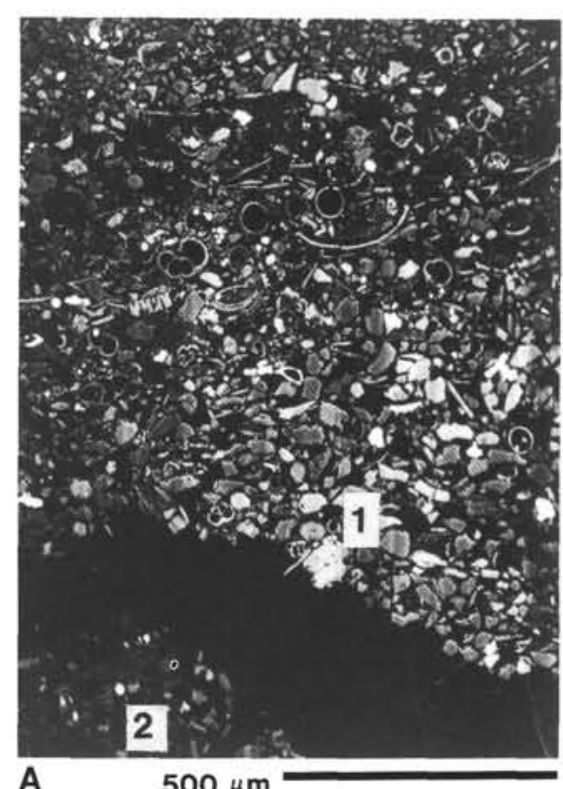

A

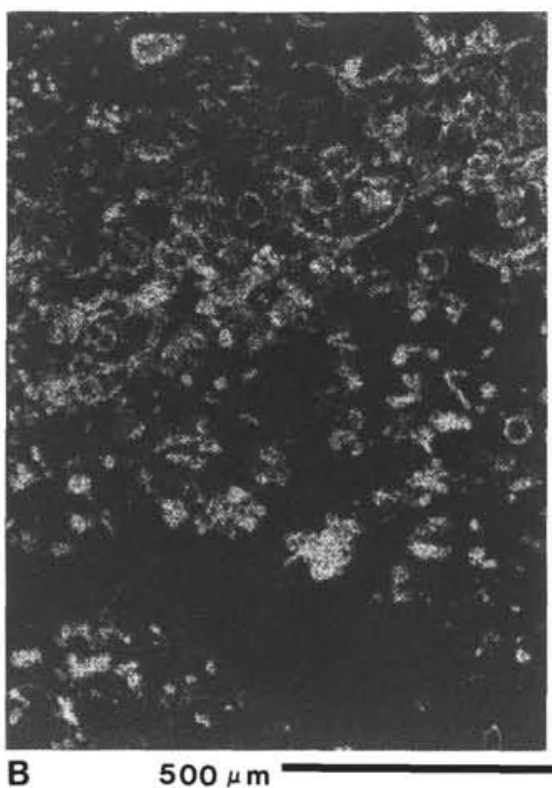

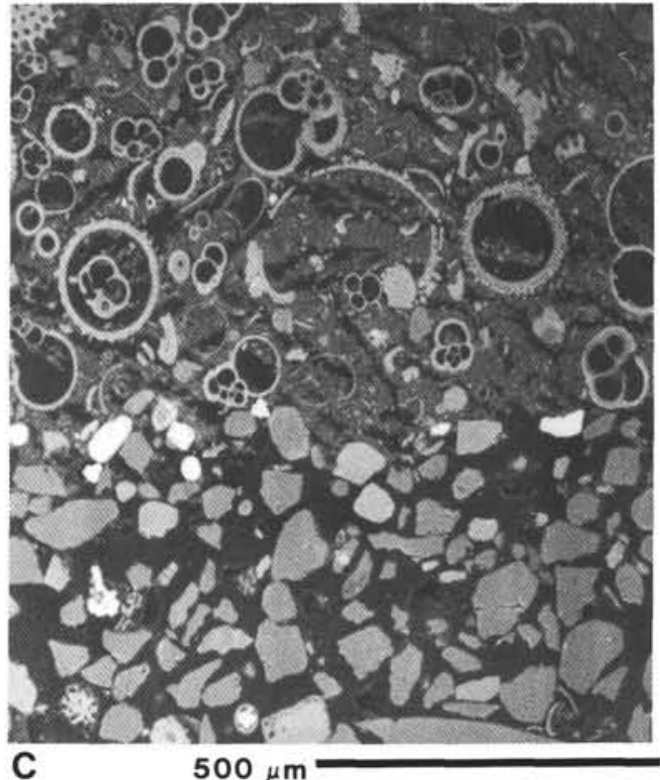

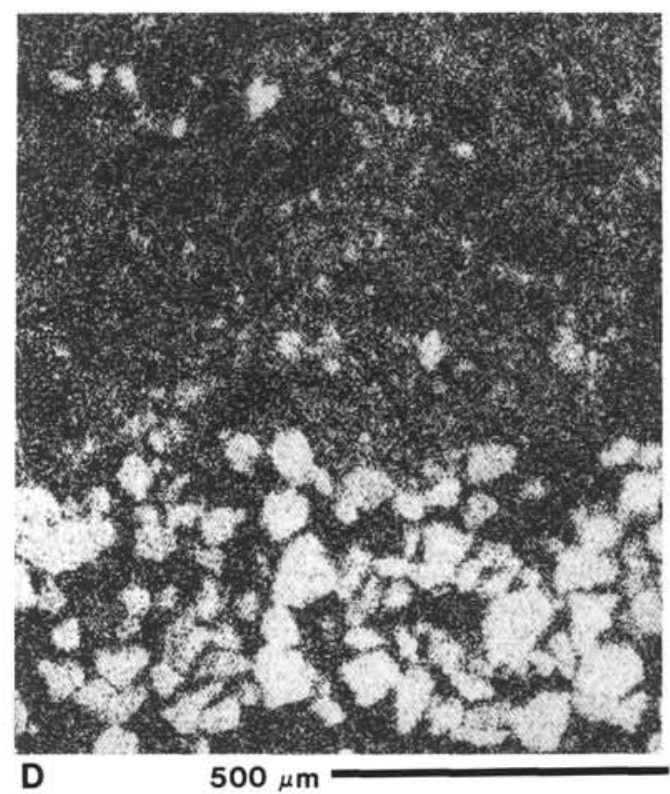

Plate 6. Component assemblage of eolian- and fluvial-sand turbidites (analyses of an impregnated polished sediment slide by SEM). A, B. Eolian-sand turbidite (Sample 108-657B-8H-3, $79 \mathrm{~cm}$ ). A. Sandy material (1) comprising eolian quartz mixed with shallow-water bioclasts and iron-oxide grains (bright white on the photograph) with overlying pelagic ooze (2) (ERD analysis). B. Calcium distribution in Plate 6A showing numerous calcareous biogenic particles (X analysis). C, D. Fluvial-sand turbidite (Sample 108-657A-1H-1, 124.5 cm). C. Sandy material showing two laminations: clastic grain-rich lamination at the base and foraminifer-rich lamination at the top (ERD); very few ironed grains are observed. D. Silica distribution in the clastic grains, showing quartz grain distribution ( $\mathrm{X}$ analysis). 